\title{
Enzyme Recovery from Biological Wastewater Treatment
}

\author{
Ziyi Liu ${ }^{1} \cdot$ Stephen R. Smith ${ }^{1}$ (1)
}

Received: 23 April 2020 / Accepted: 19 September 2020 / Published online: 12 October 2020

(c) The Author(s) 2020

\begin{abstract}
Enzymes are high value industrial bio-catalysts with extensive applications in a wide range of manufacturing and processing sectors, including the agricultural, food and household care industries. The catalytic efficiency of enzymes can be several orders higher compared to inorganic chemical catalysts under mild conditions. However, the nutrient medium necessary for biomass culture represents a significant cost to industrial enzyme production. Activated sludge (AS) is a waste product of biological wastewater treatment and consists of microbial biomass that degrades organic matter by producing substantial quantities of hydrolytic enzymes. Therefore, enzyme recovery from AS offers an alternative, potentially viable approach to industrial enzyme production. Enzyme extraction from disrupted AS flocs is technically feasible and has been demonstrated at experimental-scale. A critical review of disruption techniques identified sonication as potentially the most effective and suitable method for enzyme extraction, which can be scaled up and is a familiar technology to the water industry. The yields of different enzymes are influenced by wastewater treatment conditions, and particularly the composition, and can also be controlled by feeding sludge with specific target substrates. Nevertheless, hydrolytic enzymes can be effectively extracted directly from waste AS without specific modifications to standard wastewater treatment processes. Purification, concentration and stabilisation/immobilisation techniques can also greatly expand the industrial application and increase the economic value and marketability of enzyme products extracted from AS. Concentrated and purified AS enzymes could readily substitute inorganic and/or commercial bioenzyme catalysts in many industrial applications including, for example, leather processing, and in detergent and animal feed formulation. Enzyme extraction from AS therefore offers significant economic benefits to the Water Industry by recovering valuable resources from wastewater. They can also optimise important waste treatment processes, such as the anaerobic digestion (AD) of sewage sludge, increasing biogas and renewable energy production. The enzyme-extracted sludge exhibits improved treatment properties, such as increased settleability, dewaterability, and anaerobic digestibility for biogas production, assisting sludge management by wastewater treatment plants (WWTPs) and enabling the further utilisation of the residual sludge.
\end{abstract}

Stephen R. Smith

s.r.smith@imperial.ac.uk

1 Department of Civil and Environmental Engineering, Imperial College London, South Kensington Campus, London SW7 2AZ, UK 


\section{Graphic Abstract}

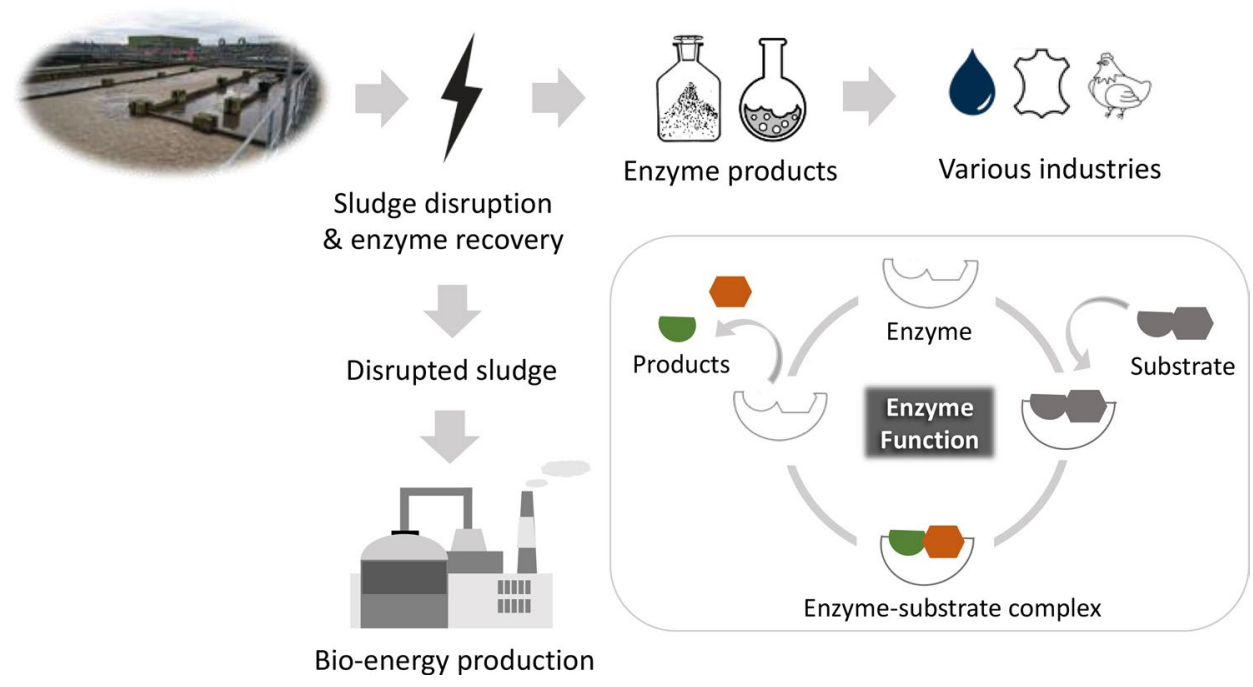

Keywords Activated sludge $\cdot$ Enzymes $\cdot$ EPS $\cdot$ Cell disruption $\cdot$ Hydrolytic $\cdot$ Resource recovery $\cdot$ Sonication $\cdot$ Wastewater treatment

\section{Statement of Novelty}

This review provides a critical assessment of the stateof-the-art of scientific developments and techniques for recovering high-value enzyme products from waste activated sludge (AS) produced by biological wastewater treatment processes. A systematic and critical summary of enzyme recovery systems is presented, which demonstrates the potential for full-scale industrial application. Critical areas of understanding include: enzyme distribution in sludge, the mechanisms of enzyme extraction and product formulation, and the technical feasibility of upscaling the enzyme recovery process in practice. The potential benefits and applications of recovered enzyme products are discussed, and recommendations for future research are provided.

\section{Introduction}

Enzymes are biocatalysts produced by cells and are involved in almost all metabolic processes performed by living organisms. The majority of enzymes are globular proteins comprising a tertiary amino acid conformation, which may, in some cases, be bound to a non-protein coenzyme or metal ion cofactor. The size of enzymes can range from less than 100 to over 2500 amino acid residues [1]. Enzymes accelerate biochemical reactions by similar mechanisms to inorganic chemical catalysts (e.g., metals, metal oxides and metal ions), by enabling molecules to overcome the energy barrier necessary for a reaction to proceed and increasing the correct orientation collision of molecules [2].

Enzyme catalysis initially involves the substrate binding to the active site of the enzyme to form an enzyme-substrate complex as an intermediate state. As the reaction progresses, the enzyme detaches from the products without being consumed itself [3]. The active sites of an enzyme consist of a small proportion of the total amino acid content (usually < 10 [1]) and have a unique shape and chemical properties that determine the catalytic specificity. The active functional groups also show a degree of mobility and can orientate to their counterparts within a substrate molecule in a favourable way [4]. An enzyme concentration in solution is commonly expressed in terms of its activity, which is defined as an enzyme unit (U): one enzyme unit $(1 \mathrm{U})$ represents the amount of enzyme that converts $1 \mu \mathrm{mol}$ of substrate or generates $1 \mu \mathrm{mol}$ of products per unit time period (e.g. min or h) under standard conditions.

Enzymes offer several key advantages over inorganic catalysts $[5,6]$. For instance, they can be extremely effective under mild conditions (i.e., ambient/physiological temperatures, atmospheric pressure and neutral $\mathrm{pH}$ ) with a catalytic efficiency several orders greater compared to inorganic catalysts. Furthermore, enzymatic reactions usually induce fewer side-reactions and generate less waste by-products. Therefore, enzymes can provide an effective, environmentally 
sustainable alternative to inorganic chemical catalysts in a wide range of industrial processes.

The global market for industrial enzymes was approximately $\$ 5.5$ billion in 2018 and is expected to rise to $\$ 7.0$ billion by 2023 , representing an annual growth rate of $4.9 \%$ $[7,8]$. Hydrolytic enzymes, such as proteases, amylases and lipases, constitute the majority of the world market [9] and are used extensively in various industries including food, leather and biodiesel production [10-13], reducing dependency on environmentally-harmful chemicals (e.g. sodium sulphide in leather tanning [10]).

Commercial enzymes are typically extracted from the biomass of bacteria, or different types of fungi, including yeast, produced in an industrial fermentation process. Industrial enzyme production uses carefully formulated culture media, to provide all the essential nutrients necessary for microbial growth, followed by further consolidation and purification [14]. Enzymes are extracted by disrupting the biomass and are formulated into marketable solid or liquid products by the addition of stabilisers (neutral salts such as ammonium sulphate or low molecular weight polyols such as glycerol or sorbitol), designed to maintain the protein conformation, and standardising agents (salts or carbohydrates such as starch, maltodextrins and sugar alcohols), to dilute the extracted enzymes to a standardised activity [15]. Synthetic culture media, in particular, represent one of the most significant costs for commercial enzyme production, equivalent to $30-40 \%$ of the total manufacturing cost [16]. Therefore, high costs of production translate into a high market retail price and, consequently, enzymes produced by standard industrial methods are generally too expensive for wide adoption in large-scale and continuous industrial processes [17]. Thus, alternative, more cost-effective approaches to producing hydrolytic microbial biomass, avoiding the need for synthetic growth media, would offer significant commercial advantages for industrial enzyme production.

Wastewater treatment is essential to protect human health and the environment and involves a series of physico-chemical and biological processes to remove pollutants from the wastewater stream, producing a residual by-product, sewage sludge. The main stages of wastewater treatment include: primary sedimentation, followed by biological treatment by the activated sludge (AS) process [18]. Total sludge production from wastewater treatment within the European Union is almost $10 \mathrm{M} \mathrm{t}$ dry solids (DS) [19] and the treatment and management of sewage sludge residues is a highly topical subject [20]. Recycling to farmland as a fertiliser and soil conditioner is the main approach to sludge management adopted in the majority of countries globally, however, other significant opportunities exist to recover potentially more valuable resources from sludge [21]. Drivers to increase value recovery in wastewater and sludge treatment systems include offsetting the significant costs associated with sludge handling and management [22], which account for up to $60 \%$ of the total operating cost of wastewater treatment plant (WWTP), as well as supporting circular economy as a whole.

Recently, biological sludge generated during wastewater treatment by the AS process has been identified as potentially an alternative source of biomass for industrial enzyme extraction [23]. Within the AS process, a diverse community of prokaryotic and eukaryotic microorganisms develop in suspended floc structures (up to $2 \mathrm{~mm}$ diameter) and degrade non-settable organic substrates in wastewater by producing substantial quantities of hydrolytic enzymes (e.g. protease, lipase, $\alpha$-glucosidase, $\alpha$-amylase, cellulase, dehydrogenase and phosphatase). These enzymes specifically cleave the sensitive linkage/bonding of large organic polymer molecules to produce simpler monomer units that can transfer across the cell membrane to be metabolised by bacteria [24, 25]. The majority of hydrolytic enzymes are either adsorbed to the cell surface or embedded in extracellular polymeric substances (EPS) surrounding bacterial cells [26]. Several studies [27-29] report the extraction of crude enzymes from biological wastewater treatment by disrupting AS flocs. This represents the first step towards developing the potential commercial scale recovery of hydrolytic enzyme products from this waste biomass source.

This paper will examine the feasibility of hydrolytic enzyme production from WWTP through a critical review of extraction techniques and conditions that influence enzyme recovery efficiency and activity from AS. Approaches to purify and stabilise enzymes extracted from AS will be examined to establish possible strategies to formulate commercially viable industrial enzyme products from this biomass source. Finally, the potential markets and applications for recovered enzymes from AS will be explored.

\section{Enzyme Location in Activated Sludge}

\section{Extracellular Enzyme Distribution Patterns Within Activated Sludge Flocs}

Microorganisms assimilate organic substrates in the AS process by producing a wide range of enzymes to catalyse the hydrolysis of large organic polymer molecules into smaller units that can be transported across the microbial cell membrane to be metabolised [26]. Various extracellular enzymes (including amylase, glucosidase, phosphatase, lipase, etc.) have been detected in AS flocs (Table 1). Therefore, AS provides an excellent matrix for recovery of complex enzyme mixtures that may be formulated into compound enzyme products for industrial application.

However, enzymes are not evenly distributed within AS flocs. Hydrolytic enzymes are not usually found in the free 
Table 1 Enzymes detected in activated sludge and their distribution in sludge flocs

\begin{tabular}{llll}
\hline Enzymes & $\begin{array}{l}\text { Bulk aqueous fraction } \\
(\%)\end{array}$ & $\begin{array}{l}\text { Microbial cells +EPS } \\
(\%)\end{array}$ & References \\
\hline $\begin{array}{l}\text { Phosphatase, cyclic phosphodiesterase, } \\
\text { glycosidase and aminopeptidase }\end{array}$ & $<5$ & $>95$ & {$[34]$} \\
$\begin{array}{l}\alpha \text {-Amylase } \\
\text { Protease and } \alpha \text {-glucosidase }\end{array}$ & Negligible & Detected & {$[35]$} \\
Leucine aminopeptidase & $\sim 4$ & $\sim 96$ & {$[36]$} \\
$\alpha$-Glucosidase & $\leq 3$ & 97 & {$[37]$} \\
Phosphatase & 7 & 93 & {$[38]$} \\
Leucine aminopeptidase & 1 & 99 & {$[39]$} \\
$\beta$-Glucosidase & 15.5 & 84.5 & \\
Lipase & 11.2 & 88.8 & {$[40]$} \\
Protease, $\alpha$-amylase and & 18.3 & 81.7 & \\
$\alpha$-glucosidase & Negligible & $\sim 100$ &
\end{tabular}

water phase of sludge flocs but are mainly detected outside of the cell (and are therefore extracellular), either attached to the cell wall or embedded within the EPS fraction of microbial cells. Extracellular polymeric substances represent a complex mixture of bacterial metabolites (including proteins, polysaccharides, lipids, humic compounds, nucleic acids, etc.) that locate outside the bacteria cell [26]. The EPS forms a negatively-charged, three-dimensional gel-like structure (Fig. 1a) due to hydrogen bond and cation bridging effects between the polysaccharide and protein components [30]. The gel-like EPS fills the void space between adjacent microbial cells, acting as an "adhesive" material that maintains the structural integrity and mechanical stability of the floc; it also provides a protective layer for the embedded microbial biomass against extreme external environmental conditions (for instance,

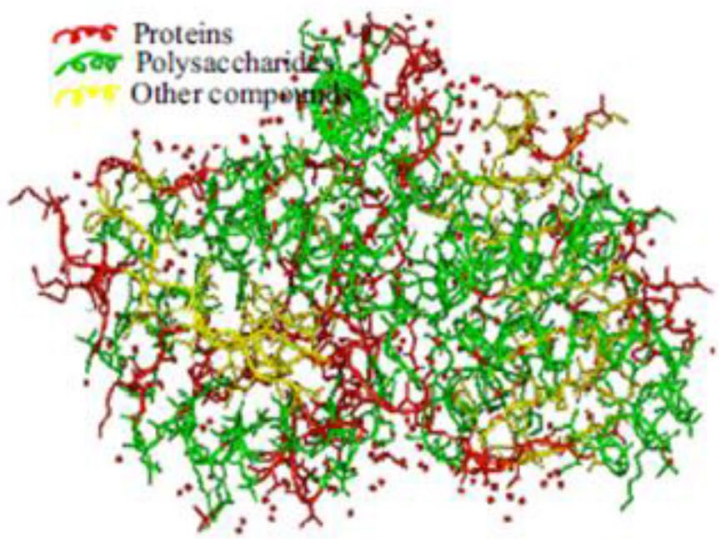

a

Fig. 1 a Chemical structure of microbial extracellular polymeric substances (EPS); b Spatial distribution of different EPS fractions and the relationship with a bacteria cell (tightly bound EPS (TB-EPS) sudden changes in $\mathrm{pH}$ or the presence of toxic substances) [31-33].

Different hydrolytic enzymes have been found within the tightly bound and loosely bound EPS (TB-EPS and LBEPS, respectively) fractions present in AS flocs (Fig. 1b). For example, Boczar et al. [24] detected esterase, lipase and leucine aminopeptidase in the easily extracted EPS (and presumably, therefore, although not specifically assigned to, the LB-EPS fraction); other enzymes (including phosphatase, valine aminopeptidase, phosphohydrolase and some glucosyl hydrolases) were mainly tightly bound to microbial cells. Cadoret et al. [42] showed that 9-24, 4-6, $15-28$ and $21-67 \%$ of the total leucine aminopeptidase, $\alpha$-glucosidase, protease and $\alpha$-amylase was detected in LBEPS, respectively. Indeed, Yu et al. [40] indicated that protease $(98.4 \%)$ was mainly tightly bound to the cell surface, whereas $\alpha$-amylase (44-65\%) and $\alpha$-glucosidase (59-100\%)

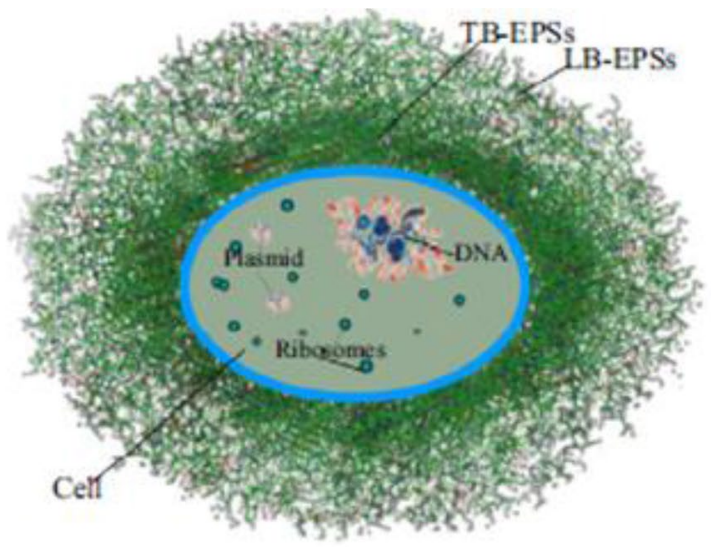

b

is the fraction that is closely associated with the cell; loosely bound EPS (LB-EPS) diffuses from TB-EPS and is located at the outer region of cellular EPS) [41] 
activities were largely associated with LB-EPS, and only limited protease, $\alpha$-amylase, or $\alpha$-glucosidase activity was detected within the TB-EPS fraction.

The mechanism of enzyme stabilisation in the extracellular fraction of sludge flocs is not clearly understood [43]. It is possible that ionic and hydrophobic interactions contribute to the immobilisation and stabilisation of hydrolytic enzymes within the sludge matrix [44]. Wingender et al. [26] suggested that the interaction between enzymes and polysaccharides was responsible for the preservation of enzymes within EPS. Frolund et al. [45] proposed that complexation with humic compounds in EPS was also involved in enzyme stabilisation.

The majority of published literature, summarised in Table 1, indicates the glycolytic enzyme activity resides mainly in the sludge floc EPS, with relatively little or no activity in the bulk aqueous fraction. Interestingly, however Guellil et al. [46] found the opposite behaviour to be the case. Guellil et al. [46] argued that readily bio-hydrolysable substrates were depolymerised by free enzymes present in the wastewater colloidal fraction. Presumably the enzymes were released by free, non-floc forming bacteria, and/or originated and survived from hydrolysis reactions that took place during transportation of raw wastewater in-sewer. Consequently, only recalcitrant, slowly biodegradable polymers (such as cellulose and lipopolysaccharides) were identified and these were removed by physicochemical adsorption onto the sludge matrix, rather than bio-degradation, forming structural elements that contributed to sludge floc stability. Evidently, the enzyme distribution patterns in biological wastewater treatment systems are dynamic and complex. However, it would appear that the biomass in AS flocs is capable of producing glycolytic enzymes and these are present in the EPS, in response to the presence of degradable polysaccharides in settled sewage.

\section{Influence of Substrate Incorporation}

Organic substances with a particle size $<0.001 \mu \mathrm{m}$ (soluble) are rapidly degraded by AS microorganisms whereas materials $>1 \mu \mathrm{m}$ (supracolloidal and/or non-settable), which constitute approximately $50-60 \%$ of the total organic matter in settled primary effluent [47], are assimilated at a much slower rate [48, 49]. The EPS fraction of sludge flocs acts as the primary surface contacting the settled primary effluent and provides sites for physical removal followed by preliminary degradation of insoluble organic substrates. The extremely large surface area of EPS, and the presence of a large number of hydrophobic groups [50], means that exogenous macromolecules and particulates are effectively scavenged and adsorbed into the sludge floc matrix from the free aqueous phase of wastewater. Subsequently, the hydrolytic enzymes accumulated within the EPS matrix rapidly react with adsorbed materials, producing smaller molecular units that can be absorbed by cells for metabolism.

The distribution of different enzymes is greatly influenced by the mobility of substrates, which is determined by the molecular weight and the extent to which they transmit through the EPS matrix [51]. Thus, substrates of higher molecular weight are less mobile, compared to smaller molecules, and accumulate within the outer EPS fraction resulting in the corresponding increase in hydrolytic enzyme activity [42]. Consequently, sludge flocs in suspended growth, biological wastewater treatment reactors, develop an efficient, diverse, stable enzyme pool, which operates synergistically and/or synchronously to degrade polymeric organic compounds without extra substrate or metabolic energy transfer for enzyme maintenance and production.

\section{Crude Enzyme Extraction from Activated Sludge}

\section{Extraction Protocol}

As most hydrolytic enzymes in sludge flocs are extracellular, and are either attached to the cell wall or embedded within the sludge EPS, crude enzyme extraction from AS can be achieved by disrupting the sludge flocs and harvesting microbial EPS. Figure 2 shows the general steps and procedures to extract enzymes from AS. Typically, AS is centrifuged to remove the bulk water fraction that contains little extracellular enzymes. The solid sediment is subjected to floc disruption (with either physical or chemical methods, alone or in combination); dilution of the sludge may be

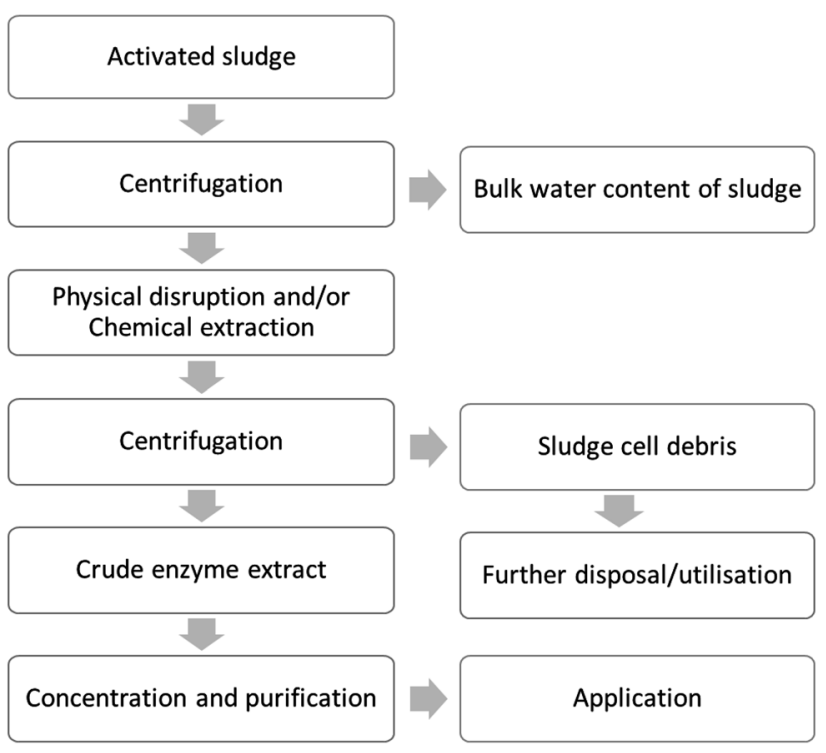

Fig. 2 Typical stages to enzyme extraction from activated sludge 
necessary prior to disruption depending on the conditions. The crude enzyme product, after solid/liquid separation, is subsequently concentrated and stabilised for application.

A wide range of techniques have been reported in the literature to extract crude enzymes from AS (Table 2), and the optimum conditions tend to be specific for different enzymes. The most frequently applied techniques, shown in Table 2, and their mechanisms of action, are critically discussed in the following sections.

\section{Physical Disruption}

\section{Sonication}

Mechanisms of Enzyme Release by Ultrasonic Treatment Sonication is a practicable technology [57] that has been applied at full-scale in the wastewater industry for waste sludge pretreatment to improve the anaerobic digestion (AD) of sewage sludge. This is achieved by disrupting the biomass to shorten the hydrolytic phase of fermentation, increase the production of biogas as a source of renewable energy and to improve the mineralization and stability of fermented sludge [57, 58]. As sonication causes cellular disruption it is also a suitable technique for extracting enzymes from AS.

The initial direct effect of sonication treatment of AS is the breakdown of sludge flocs, exposing microbial cells to the aqueous environment and increasing the vulnerability to further ultrasonic destruction. The release of extracellular and intracellular substances containing enzymes from the sludge occurs upon cellular destruction. Balasundaram and Harrison [59] suggested that enzymes are released following the stepwise breakdown of the cell structure by sonication treatment, as illustrated in Fig. 3. Cadoret et al. [42] found that the ultrasound treatment of AS significantly shifted the floc size distribution of disrupted sludge towards smaller size classes, reducing the median diameter of the flocs from 91 to $37 \mu \mathrm{m}$. The frequency of small flocs was, therefore, also increased; $99 \%$ of the particles had a mean diameter of $<4 \mu \mathrm{m}$ in the disrupted sludge, compared to $6-600 \mu \mathrm{m}$ in untreated flocs. Zielewicz [60] indicated that disrupted microbial flocs with a particle size smaller than $100 \mu \mathrm{m}$ were more likely to release cellular substances compared to larger flocs. Thus, reducing the floc size by sonication also aids the mechanism of enzyme extraction from AS.

The disruption of sludge flocs and cells is caused by the cavitation effect of ultrasound treatment [61, 62]. High frequency acoustic signals pass through the liquid medium and the compression and expansion cycles of the sound waves create bubbles or cavities in the liquid. Two types of cavities, stable and inertial, form depending on the pressure level and other ambient conditions [63]. Stable cavities typically oscillate non-linearly around an equilibrium size and for many cycles of the acoustic pressure without collapse. By contrast, inertial cavities expand significantly before violently collapsing and, consequently, are much more important for cell disruption [64]. Inertial cavities can expand to many times their original size in response to the applied acoustic pressure [65]. When the negative pressure exerted exceeds the local tensile strength of the liquid, the implosive collapse of the bubbles releases a shock wave. Shock waves propagate in the surrounding medium, forming jet streams initiating hydrodynamic shear forces that disrupt cell membranes. The size of the inertial cavities at which collapse occurs is described as the linear resonance size $\left(R_{0}\right)[64$, 66] as follows:

$R_{0}=\sqrt{\frac{3 \gamma P_{\infty}}{\rho \omega^{2}}}$

where, $\gamma$ is the specific heat ratio of the gas; $P_{\infty}$ is the ambient liquid pressure; $\rho$ is the liquid density; and $\omega$ is the driving frequency of the acoustic field.

Factors Influencing the Efficiency of Enzyme Extraction by Sonication The performance of ultrasound at extracting enzymes from cellular biomass depends on several critical operational conditions, including:

Ultrasound Frequency: Yu et al. [53] sonicated AS to extract extracellular and intracellular enzymes and found that low frequency ultrasound at $20 \mathrm{kHz}$ was more effective than $40 \mathrm{kHz}$, and increased the activity of $\alpha$-amylase, alkaline phosphatase and acid phosphatase to approximately 20, 16 and $6 \mathrm{U} / \mathrm{g}$ volatile solids (VS) compared to approximately $17,<1$ and $<1 \mathrm{U} / \mathrm{g}$ VS at the higher frequency, respectively. Indeed, most studies on enzyme recovery use an ultrasound frequency in the range $20-25 \mathrm{kHz}[29,54,55]$. The better performance of lower frequency ultrasound may be explained because it generates larger cavitation bubbles that produce stronger shear forces when they implode in the fluid, which is more disruptive to microbial cells, compared to the smaller cavitation bubbles formed at high frequencies (e.g. $>200 \mathrm{kHz}$ ) [67]. Ultrasound frequencies above $30 \mathrm{kHz}$ can also denature the protein structure of enzymes, mainly because of the marked increase in local pressure and temperature changes caused by the intensive collapse of small cavity bubbles $[68,69]$. Furthermore, the intensity of applied ultrasound, necessary to overcome the cohesive forces of the liquid media and achieve a given degree of cavitation to create voids, is correspondingly increased at higher frequencies [70]. This is explained because the cycle of compression and expansion caused by ultrasound is shorter at higher frequencies and, therefore, molecules of the liquid cannot effectively separate to form voids. Consequently, the power requirement to initiate cavitation is much greater for highfrequency sonication [70]. Sponer [71] proposed that the 
Table 2 Methods for crude enzyme extraction from activated sludge

\begin{tabular}{|c|c|c|c|c|}
\hline Method & $\begin{array}{l}\text { Optimum } \\
\text { extraction conditions }\end{array}$ & Target enzymes & $\begin{array}{l}\text { Enzyme activity (U) in crude } \\
\text { extract }\end{array}$ & References \\
\hline $\begin{array}{l}\text { End-over-end rotation with } \\
\text { PBS and FDA solution; incu- } \\
\text { bation at room temperature }\end{array}$ & $\begin{array}{l}\text { Direct detection in AS without } \\
\text { optimisation }\end{array}$ & $\begin{array}{l}\text { Esterase } \\
\text { Ala-aminopeptidase } \\
\alpha \text {-Glucosidase } \\
(1 \mathrm{U}: 1 \mu \mathrm{mol} \text { product rele }\end{array}$ & $\begin{array}{l}120 \mathrm{U} / g \text { VS } \\
1060 \mathrm{U} / g \text { VS } \\
40 \mathrm{U} / \mathrm{g} \mathrm{VS}\end{array}$ & {$[52]$} \\
\hline Stirring with CER & $\begin{array}{l}\text { Dosage }=70-75 \mathrm{~g} / \mathrm{g} \text { VS } \\
\text { Stirring at } 600 \mathrm{rpm} \text { for } 1 \mathrm{~h} \\
4{ }^{\circ} \mathrm{C}\end{array}$ & $\begin{array}{l}\text { Esterase } \\
\text { Leucine aminopeptidase } \\
\alpha \text {-Glucosidase } \\
\beta \text {-Glucosidase } \\
\text { Lipase } \\
\beta \text {-Glucuronidase } \\
\text { Chitinase } \\
(1 \mathrm{U}: 1 \mu \mathrm{mol} \text { product rele }\end{array}$ & $\begin{array}{l}35 \mathrm{U} / g \text { VS } \\
13 \mathrm{U} / g \text { VS } \\
<10 \mathrm{U} / g \text { VS } \\
\sim 10 \mathrm{U} / g \text { VS } \\
<10 \mathrm{U} / g \text { VS } \\
<10 \mathrm{U} / g \text { VS } \\
<10 \mathrm{U} / g \text { VS }\end{array}$ & [45] \\
\hline Fractionation by Dyno Mill & $\begin{array}{l}\text { Glass beads (diame- } \\
\text { ter }=0.5 \mathrm{~mm}) \\
\text { Bead loading }=60 \%(\mathrm{v} / \mathrm{v}) \\
\text { Agitating speed of mill- } \\
\text { ing }=3200 \mathrm{rpm}\end{array}$ & (1 U: undefined) & $\begin{array}{l}\sim 5 \mathrm{U} / \mathrm{g} \text { protein for diary sludge } \\
40 \mathrm{U} / \mathrm{g} \text { protein in municipal } \\
\text { sludge }\end{array}$ & {$[27]$} \\
\hline Stirring with CER & $\begin{array}{l}\text { Dosage }=60-70 \mathrm{~g} / \mathrm{g} \text { VS } \\
\text { Stirring at } 900 \mathrm{rpm} \text { for } 1 \mathrm{~h}\end{array}$ & $\begin{array}{l}\text { Lipase } \\
\text { Protease }\end{array}$ & $\begin{array}{l}\sim 210 \mathrm{U} / \mathrm{g} \text { VS } \\
\sim 300 \mathrm{U} / \mathrm{g} \mathrm{VS}\end{array}$ & {$[28]$} \\
\hline Stirring with TX100 & $\begin{array}{l}\text { Dosage }=0.1 \% \text { for lipase, } 0.5 \% \\
\text { for protease } \\
\text { Stirring at } 900 \mathrm{rpm} \text { for } 1 \mathrm{~h}\end{array}$ & $\begin{array}{l}\text { Lipase } \\
\text { Protease }\end{array}$ & $\begin{array}{l}\sim 320 \mathrm{U} / \mathrm{g} \text { VS } \\
\sim 4000 \mathrm{U} / \mathrm{g} \text { VS }\end{array}$ & [28] \\
\hline Stirring with EDTA & $\begin{array}{l}\text { Dosage }=10 \mathrm{mM} \\
\text { Stirring at } 900 \mathrm{rpm} \text { for } 1 \mathrm{~h}\end{array}$ & $\begin{array}{l}\text { Lipase } \\
\text { Protease }\end{array}$ & $\begin{array}{l}\sim 250 \mathrm{U} / \mathrm{g} \text { VS } \\
\sim 1700 \mathrm{U} / \mathrm{g} \text { VS }\end{array}$ & {$[28]$} \\
\hline Sonication with TX100 & $\begin{array}{l}\text { Frequency }=15 \mathrm{kHz} \\
\text { Duration }=30 \mathrm{~min} \\
\text { Power }=\sim 200 \mathrm{~W} \\
\text { Dosage }=0.1 \% \mathrm{TX} 100\end{array}$ & $\begin{array}{l}\text { (1 U for lipase: } 1 \mathrm{mmol} p \\
1 \mathrm{U} \text { for protease: } \mathrm{UV} \text { abs }\end{array}$ & $\begin{array}{l}\text { released/min; } \\
\text { increase of } 0.01 \text { at } 440 \mathrm{~nm} \text { ) }\end{array}$ & {$[28]$} \\
\hline Sonication & $\begin{array}{l}\text { Frequency }=20 \mathrm{kHz} \\
\text { Duration }=10 \mathrm{~min} \\
\text { Specific power input }=552 \mathrm{~W} / \mathrm{g} \\
\text { DS } \\
4{ }^{\circ} \mathrm{C}\end{array}$ & $\begin{array}{l}\text { Protease } \\
\alpha \text {-Amylase } \\
\beta \text {-Glucosidase } \\
\text { Alkaline phosphatase } \\
\text { Acid phosphatase }\end{array}$ & $\begin{array}{l}\sim 3 \mathrm{U} / \mathrm{g} \text { VS } \\
\sim 20 \mathrm{U} / g \text { VS } \\
<1 \mathrm{U} / \mathrm{g} \text { VS } \\
\sim 10 \mathrm{U} / g \text { VS } \\
\sim 4 \mathrm{U} / \mathrm{g} \mathrm{VS}\end{array}$ & {$[53]$} \\
\hline Stirring with EDTA & $\begin{array}{l}\text { Dosage }=2 \% \\
\text { Stirring at } 600 \mathrm{rpm} \text { for } 3 \mathrm{~h} \\
4{ }^{\circ} \mathrm{C}\end{array}$ & $\begin{array}{l}\text { Protease } \\
\alpha \text {-Amylase } \\
\beta \text {-Glucosidase } \\
\text { Alkaline phosphatase } \\
\text { Acid phosphatase } \\
(1 \mathrm{U}: 1 \mu \mathrm{mol} \text { product rele }\end{array}$ & $\begin{array}{l}<1 \mathrm{U} / g \text { VS } \\
\sim 40 \mathrm{U} / \mathrm{g} \text { VS } \\
\text { Very low } \\
\text { Very low } \\
\sim 1 \mathrm{U} / \mathrm{g} \mathrm{VS} \\
\text { in) }\end{array}$ & {$[53]$} \\
\hline Sonication with TX100 & $\begin{array}{l}\text { Frequency }=24 \mathrm{kHz} \\
\text { Power intensity }=4 \mathrm{~W} / \mathrm{cm}^{2} \\
\text { Duration }=10 \text { min for protease, } \\
20 \text { min for lipase } \\
\text { Dosage }=2 \% \mathrm{TX} 100\end{array}$ & $\begin{array}{l}\text { Protease } \\
\text { Lipase }\end{array}$ & $\begin{array}{l}\sim 53 \mathrm{U} / \mathrm{g} \mathrm{VS} \\
\sim 21 \mathrm{U} / \mathrm{g} \mathrm{VS}\end{array}$ & [29] \\
\hline Stirring with CER and TX100 & $\begin{array}{l}\text { Dosage }=0.48 \mathrm{~g} / \mathrm{mL} \text { CER, } \\
0.5 \% \mathrm{TX} 100 \\
\text { Stirring at } 500 \mathrm{rpm} \text { for } 1 \mathrm{~h} \\
\text { Ice-water bath }\end{array}$ & (1 U: $1 \mu \mathrm{mol}$ product rele & $\begin{array}{l}7.0 \mathrm{U} / \mathrm{g} \mathrm{VS} \\
15.5 \mathrm{U} / \mathrm{g} \mathrm{VS}\end{array}$ & [29] \\
\hline Sonication with TX100 & $\begin{array}{l}\text { Frequency }=24 \mathrm{kHz} \\
\text { Duration }=30 \mathrm{~min} \\
\text { Power intensity }=3.9 \mathrm{~W} / \mathrm{cm}^{2} \\
\text { Dosage }=2 \% \mathrm{TX} 100 \\
\text { Ice-water bath }\end{array}$ & $\begin{array}{l}\text { Protease } \\
\text { Lipase }\end{array}$ & $\begin{array}{l}52 \mathrm{U} / g \mathrm{VS} \\
\sim 21 \mathrm{U} / \mathrm{g} \mathrm{VS}\end{array}$ & {$[54]$} \\
\hline
\end{tabular}


Table 2 (continued)

\begin{tabular}{|c|c|c|c|c|}
\hline Method & $\begin{array}{l}\text { Optimum } \\
\text { extraction conditions }\end{array}$ & Target enzymes & $\begin{array}{l}\text { Enzyme activity (U) in crude } \\
\text { extract }\end{array}$ & References \\
\hline & & \multicolumn{3}{|c|}{ (1 U: $1 \mu \mathrm{mol}$ product released/min) } \\
\hline Sonication with TX100 & $\begin{array}{l}\text { Frequency }=24 \mathrm{kHz} \\
\text { Duration }=30 \mathrm{~min} \\
\text { Power intensity }=3-7.4 \mathrm{~W} / \mathrm{cm}^{2} \\
\text { Dosage }=0.1 \% \mathrm{TX} 100 \\
\text { Ice-water bath }\end{array}$ & Lipase & $450 \mathrm{U} / \mathrm{g} \mathrm{VS}$ & {$[43]$} \\
\hline Stirring with CER & $\begin{array}{l}\text { Dosage }=40-60 \mathrm{~g} / \mathrm{g} \text { VS } \\
\text { Stirring at } 1000 \mathrm{rpm} \text { for } 1 \mathrm{~h} \\
\text { Ice-water bath }\end{array}$ & $\begin{array}{l}\text { Lipase } \\
\text { Protease }\end{array}$ & $\begin{array}{l}200 \mathrm{U} / \mathrm{g} \text { VS } \\
700 \mathrm{U} / \mathrm{g} \mathrm{VS}\end{array}$ & {$[43]$} \\
\hline \multirow[t]{2}{*}{ Stirring with TX100 } & $\begin{array}{l}\text { Dosage }=0.1 \% \text { for lipase, } 1.0 \% \\
\text { for protease } \\
\text { Stirring at } 1000 \mathrm{rpm} \text { for } 1 \mathrm{~h} \\
\text { Ice-water bath }\end{array}$ & $\begin{array}{l}\text { Lipase } \\
\text { Protease }\end{array}$ & $\begin{array}{l}400 \mathrm{U} / \mathrm{g} \text { VS } \\
3600 \mathrm{U} / \mathrm{g} \text { VS }\end{array}$ & [43] \\
\hline & & \multicolumn{3}{|c|}{$\begin{array}{l}\text { ( } 1 \mathrm{U} \text { for lipase: } 1 \mathrm{mmol} \text { product released/min; } \\
1 \mathrm{U} \text { for protease: } \mathrm{UV} \text { absorbance increase of } 0.01 \text { at } 440 \mathrm{~nm} \text { ) }\end{array}$} \\
\hline Sonication & $\begin{array}{l}\text { Frequency }=20 \mathrm{kHz} \\
\text { Duration }=10 \mathrm{~min} \\
\text { Power density }=1 \mathrm{~W} / \mathrm{mL}\end{array}$ & $\begin{array}{l}\text { Phosphatase } \\
\text { Galactosidase } \\
\text { Glucuronidase } \\
\text { (1 U: } 1 \mu \mathrm{g} \text { product released/h) }\end{array}$ & $\begin{array}{l}\sim 38 \mathrm{U} / \mathrm{mg} \text { protein } \\
\sim 15 \mathrm{U} / \mathrm{mg} \text { protein } \\
\sim 10 \mathrm{U} / \mathrm{mg} \text { protein }\end{array}$ & {$[55]$} \\
\hline Stirring with TX100 & $\begin{array}{l}\text { Dosage }=1.0 \% \text { TX100 } \\
60 \text { min (agitating speed not } \\
\text { specified) } \\
4{ }^{\circ} \mathrm{C}\end{array}$ & Protease & $5.1 \mathrm{U} / \mathrm{g}$ & {$[56]$} \\
\hline & & \multicolumn{3}{|l|}{ (1 U: $1 \mathrm{~mol}$ product released/min) } \\
\hline
\end{tabular}

$\mathrm{U}$ is the enzyme activity and is based on either the amount of product formed or substrate consumed within a specified, standard time period under defined experimental conditions; the metrics for enzyme activity units varied between the studies and are presented in brackets below each reference

$V S$ volatile solids; $D S$ dry solids; $P B S$ phosphate-buffered saline; FDA fluorescein diacetate; $C E R$ cation exchange resin; TX100 Triton X100, is a non-ionic surfactant; EDTA ethylene diamine tetraacetic acid, is a chelating agent; rpm revolutions per minute, is a measure of rotational speed

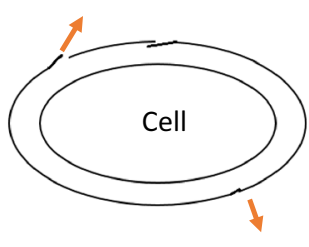

a

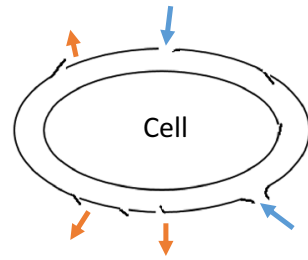

b

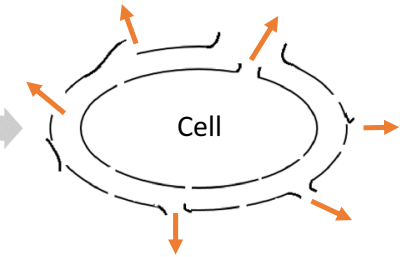

C

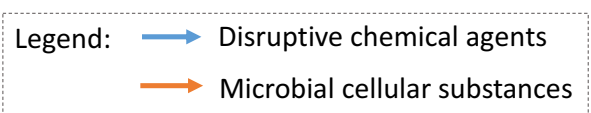

Fig. 3 Representation of the three stages of cell disruption by sonication: a Stage 1: pores form on the outer cell wall due to the external mechanical forces exerted by cavitation, releasing some periplasmic enzymes; b Stage 2: chemical agents diffuse from the external solution into the cell, generating a combined disruptive effect with the mechanical forces from sonication; and c Stage 3: cell membranes are destroyed by the continuous exposure to cavitation ("fatigue failure" of the cell structure) causing more severe cell disruption, releasing intracellular enzymes and substances (adapted from [59]) threshold acoustic intensity $\left(I_{t}\right.$, in W/ $\left./ \mathrm{cm}^{2}\right)$ required to initiate a cavitation event is linearly related to the frequency of the ultrasound $\left(f\right.$, in MHz), and was expressed by $I_{t}=0.9965 f$ -0.80 ( $p$-value $<0.001$, for $f$ ranging from 0.5 to $10 \mathrm{MHz}$, derived from [75]). Nguyen et al. [72] similarly showed that the threshold pressure of cavitation $\left(P_{t}\right.$, in $\left.\mathrm{kPa}\right)$ was linearly related to the ultrasound frequency $(f$, in $\mathrm{kHz})$, with $P_{t}=$ $0.1255 f+60.25$ ( $p$ value $<0.001$, for $f$ ranging from 22 to $4800 \mathrm{kHz}$, derived from [76]). 
Duration: Several studies [73-75] consistently show that effective cellular disruption and enzyme release by sonication requires a minimum treatment period $>10 \mathrm{~min}$. For example, Arun and Sivashanmugam [76] found that increasing the sonication duration from 5 to $20 \mathrm{~min}$ significantly improved the recovery of protease, lipase and amylase from fruit waste and measured maximum enzyme activity values equivalent to approximately 43,17 and $27 \mathrm{U} /$ $\mathrm{ml}$, respectively. However, extending the sonication period to 50 min reduced the enzyme activities by 76,41 and $81 \%$, respectively. This can be caused by a number of factors, but, released enzymes are particularly sensitive to thermal damage from increased energy dissipation as heat from excessive energy inputs to biomass associated with prolonged sonication times (see below). Thus, uncontrolled increases in temperature by sonication treatment can be detrimental to the protein structure of most enzymes, but can be effectively avoided by: (1) applying an optimal sonication duration, (2) carrying out sonication treatment in the laboratory in an icewater bath (see Table 2) or with a coolant circulation system outside the treatment chamber for larger-scale, industrial processes, and/or (3) adopting a pulse-cycle mode of on/off operation.

Energy Level: The energy supplied for cellular disruption by sonication treatment can be expressed in several ways, shown as follows [77]:

Specific energy $(\mathrm{kJ} / \mathrm{kg})=\frac{P_{o} \times t}{V \times S}$

$\operatorname{Energy} \operatorname{dose}(\mathrm{kJ} / \mathrm{L})=\frac{P_{o} \times t}{V}$

Power density $(\mathrm{W} / \mathrm{L})=\frac{P_{o}}{V}$

Power intensity $\left(\mathrm{W} / \mathrm{cm}^{2}\right)=\frac{P_{o}}{A}$

where, $P_{o}$ is the power input $(\mathrm{kW}) ; t$ is the sonication duration (s); $V$ is the sample volume (L); $S$ represents the solids content of the sample $(\mathrm{kg} / \mathrm{L})$; and $A$ is the area of the emitting surface of the sonication probe $\left(\mathrm{cm}^{2}\right)$.

The energy supplied by sonication treatment may be represented by any one of these different quantitative units in published studies. However, they are not readily transferrable; therefore, it is not always possible to directly or quantitatively compare the amount of sonication energy delivered for cell disruption between different reports in the literature.

Show et al. [78] argued that the impact of cavitation bubble formation, and their subsequent implosion, on AS disruption, can be viewed as a competition between the structural strength of sludge particles and the sonication intensity. Consequently, there is a critical energy intensity level above which the mechanical forces delivered by sonication will disrupt sludge flocs. However, extremely high energy intensities can be detrimental to enzyme conformation. The sonication intensity is directly proportional to the amplitude of vibration of the ultrasonic source. Thus, high sonication amplitudes generate excessive amounts of cavitation bubbles, and the shock wave from the implosion of cavities can trigger extreme shear forces in the aqueous solution. Under these conditions, the hydrogen bonds and van der Waals' interactions of the polypeptide chains can be disrupted, which are vital to maintaining the structural integrity of enzymes [70, 79].

Indeed, Yu et al. [53] showed that ultrasound intensity was more important than the duration for controlling the efficiency of enzyme extraction. Thus, the DNA content of crude enzyme extracts, which provides an indicator of sludge floc disruption and the release of cellular substances, was small and $<7 \mathrm{mg} / \mathrm{g} \mathrm{VS}$ at a fixed specific power input of $138 \mathrm{~W} / \mathrm{g}$ DS, irrespective of the sonication duration (2-20 $\mathrm{min})$. In contrast, at a fixed duration $(10 \mathrm{~min})$, the DNA content was significantly increased with increasing power input from 138 to $690 \mathrm{~W} / \mathrm{g}$ DS, and the maximum DNA release (approximately $15 \mathrm{mg} / \mathrm{g}$ DS) was measured at $552 \mathrm{~W} / \mathrm{g}$ DS. Zielewicz [60] recommended that a sonication device with a power density of $880 \mathrm{~W} / \mathrm{L}$ was necessary for maximum sludge floc disintegration. Indeed, the maximum recovery of protease, equivalent to $63 \%$, from AS disruption in the laboratory experiments of Liu and Smith [23] was obtained with an ultrasound frequency of $20 \mathrm{kHz}$, a power density of $872 \mathrm{~W} / \mathrm{L}$ and $10 \mathrm{~min}$ duration. For continuous commercial application, Zielewicz [80] suggested that the sonication duration, which is associated with the hydraulic retention time in the disintegration chamber, should provide an energy density ranging from 5 to $25 \mathrm{kWh} / \mathrm{m}^{3}$ (equivalent to an energy dose of $18-90 \mathrm{~kJ} / \mathrm{L}$ ).

Solids Content in Sludge: Ultrasonic conditions for effective cell disruption are often specific to the characteristics of the target material [57]. The core principle of sonication treatment is the conversion of electrical energy into mechanical vibrations that generate cycles of cavitation bubble formation and collapse, producing biologically disruptive shear forces at the cellular level. Consequently, sonication devices (typically a sonication probe) have an effective functioning range over which the energy is gradually dissipated, depending on the physicochemical characteristics, and particularly the solids content, of the sample material [81].

Sonication disruption of AS for enzyme extraction is usually performed on liquid sludge and so it is necessary to consider the optimum solids content of the sludge for cell disruption. Solids concentrations above the optimum increase sludge viscosity and the absorption of ultrasound energy by particulate matter [82]. Therefore, the optimum 
solids content and cell disruption are related to the energy consumption efficiency of the sonication treatment [78]. Cavitation bubble formation within the sludge matrix requires sufficient liquid for vaporisation to take place and, consequently, the development and propagation of cavitation bubbles can be severely limited above the optimum solids content [78].

Optimum DS contents reported for AS disruption by sonication are in the range of $2-4 \%$. For example, Show et al. [78] found that, at a power density of $520 \mathrm{~W} / \mathrm{L}$, significant particle size reduction of AS flocs occurred for sludge samples at $<2.9 \%$ DS, however, there was only minor disruption at higher DS contents (3.8\%). Zhang et al. [83] found the optimum DS concentration for ultrasonic treatment of AS at a power density of $80 \mathrm{~W} / \mathrm{L}$ was $2 \%$. By comparison, sonication of sludge with lower solids content $(0.5 \% \mathrm{DS})$ consumed $137 \%$ more energy, while a higher solids content (3\% DS) absorbed the sound energy and reduced the disruption efficiency. Zielewicz [60] also confirmed that lower solids concentrations (ranging from 2.8 to $4.2 \%$ DS) were more susceptible to ultrasonic disruption compared to more concentrated sludge (6.3\% DS).

The apparent range of optimum solids contents reported in the literature may be explained because sludge samples from different sources exhibit contrasting physicochemical properties with distinct structural strength characteristics that influence the susceptibility to cavitation. Activated sludge flocs represent a multiphase, complex matrix containing microorganisms, EPS, gas bubbles and dissolved and particulate organic and mineral matter. Abbasi et al. [84] and Pilli et al. [85] indicated that gas entrapment in sludge flocs can lower the cavitation threshold pressure. Richard [86] found that small flocs (usually with diameter $<50 \mu \mathrm{m}$ ), consisting only of floc-forming bacteria without a filament backbone, that commonly occur under starvation (typically when the food to microorganism ratio (F/M) [18], is very small [87], or the sludge age is extended [88]) or chronic toxicity conditions, are particularly susceptible to disruption by external forces such as ultrasound, which is consistent with other work on the effects of floc size. Zielewicz [60] suggested that the mineral/organic matter ratio of sludge was another important factor influencing the efficiency of ultrasound disruption, due to its effect on the mechanical strength, but did not explain how they were related. The mineral/organic matter ratio of AS ranges from 0.17 to 0.67 (typical value $=0.4$ ) [18]. As the sludge becomes more mineralized with increasing sludge age, the EPS content in AS flocs decreases, and the mineral/organic matter ratio and proportion of recalcitrant cellular, structural material increase [89]. Therefore, the efficiency of sonication treatment may decrease with increasing mineral/organic matter ratio of AS flocs due to the greater dissipation and absorbance of ultrasound energy by larger, non-disruptable inorganic and recalcitrant, structural organic fractions, compared to sludge with smaller ratios.

Ultrasound Treatment and Enzyme Activity Interestingly, ultrasound has been found to have a direct, positive effect on enzyme activity if the treatment is carried out in a controlled manner. For example, Liu et al. [90] investigated the effect of ultrasound on the activity of calcium ATPase (an enzyme attached to the plasma membrane that is responsible for regulating the intracellular $\mathrm{Ca}^{2+}$ concentration via expulsion of $\mathrm{Ca}^{2+}$ from the cytosol of cells) in callus cells of Aloe arborescens. Plasma membrane, containing $\mathrm{Ca}^{2+}$-ATPase, was extracted by physical chopping and homogenisation of Aloe callus cells, followed by centrifugation and chemical purification using a two-phase, aqueous polymer system. Exposing the extracted plasma membrane to a pulsed ultrasound treatment $(20 \mathrm{kHz}, 2 \mathrm{~W}, 10 \mathrm{~s}$ duration with a pulse cycle of $0.1 \mathrm{~s}$ on and $0.9 \mathrm{~s}$ off) increased the $\mathrm{Ca}^{2+}$-ATPase activity by $26 \%$ compared to the control condition without sonication. However, increasing the ultrasound energy intensity to $10 \mathrm{~W}$, delivered as a continuous wave, decreased the enzyme activity by approximately $25 \%$.

The mechanism and reason why ultrasound treatment can increase enzyme activity is not fully understood. A possible explanation is that controlled sonication treatment may induce conformational changes to the protein structure of the enzyme, by breaking covalent bonds [91]. This may release and expose more active sites in the interior of the protein to substrate molecules in the aqueous solution, increasing the apparent enzyme activity. Capelo et al. [92] suggested that sonication may also increase the efficiency of mixing and diffusion of reaction components, resulting in a higher frequency of collision between reaction substrates and active sites of the enzyme.

\section{Milling}

Mechanisms of Cell Disruption by Bead Milling Milling treatment is an effective, alternative method of cell disruption to release cellular substances from AS [93-95]. A typical bead mill consists of a grinding chamber (vertical or horizontal) filled with small beads (e.g. glass [96] or $\mathrm{ZrO}_{2}$ beads [97]), and a rotating shaft (fitted with several agitator disks) through its centre, imparting kinetic energy to the small beads. During the rotary movement of the cells and the beads, the energy is released by the collisions between beads and cells (Fig. 4), destroying the cell wall [98]. Suarez Garcia et al. [99] indicated that approximately $95 \%$ of the total energy released from collisions in the mill occurs in the vicinity of the agitators, where the beads are moving at the maximum speed. By contrast, the beads are almost static close to the shaft or chamber wall, where they have lower potential to collide with adjacent cells. Furthermore, lay- 


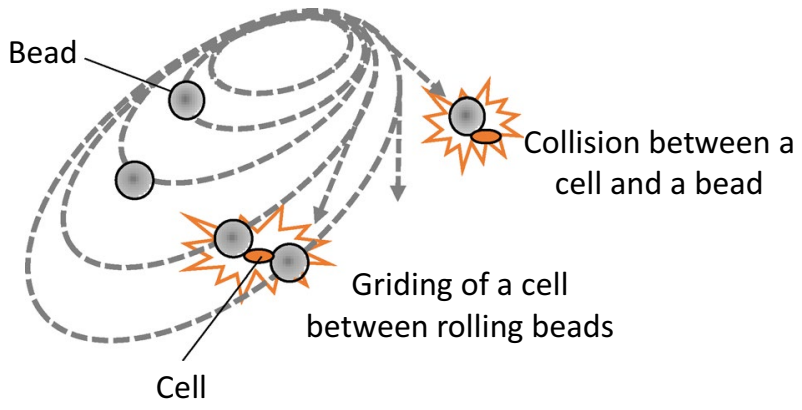

Fig. 4 Mechanisms of bead milling in microbial cell disruption (adapted from [100])

ers of rolling beads (Fig. 4) moving at different speeds can induce shear forces and the grinding effect also contributes to cellular disruption [100]. Factors Influencing the Efficiency of Enzyme Extraction
by Milling Operational Conditions Influencing Bead Milling: The progress of cell disruption against time $(t)$ by milling can be described by a first order kinetic model [101, 102], shown as follows:

Cell disruption rate $=1-e^{-k t}$

where, the first-order rate constant, $k$, represents the efficiency of the milling process at cell disruption, and can be affected by bead size, loading rate and agitation speed; in particular, the first-order rate constant $(k)$ is proportional to the square of the bead loading rate and increases with decreasing bead diameter [101, 102]. Jung et al. [27] found that the disruption rate constants $(k)$ of diary and municipal sewage sludge, under optimum conditions, were $0.22 / \mathrm{min}$ and $0.20 / \mathrm{min}$, respectively.

The efficacy of milling as an approach to sludge and cellular disruption largely depends on the collision frequency between agitated beads and cells. Consequently, bead size and loading rate (i.e., the ratio of the total bead volume to sample volume, $\mathrm{v} / \mathrm{v} \%$ ) are critical metrics for optimisation. For example, Jung et al. [27] used a continuous Dyno mill and glass beads to disrupt AS to solubilise the sludge and recover cellular proteins. An optimum solubilisation ratio (i.e., the ratio of total soluble organic carbon to total carbon of the disrupted AS) of $53 \%$ was obtained with $0.5 \mathrm{~mm}$ diameter beads, a loading rate of $60 \%(\mathrm{v} / \mathrm{v})$, and agitation speed of $3200 \mathrm{rpm}$.

The diameter of the beads used in milling has a major influence on the amount of energy required to achieve the effective disruption of AS flocs and bacterial cells. Thus, Lehne et al. [103] found the minimum, optimum specific energy value was obtained with decreasing bead diameter to $0.2 \mathrm{~mm}$. However, reducing the bead size further (for example, to $<0.1 \mathrm{~mm}$ ) limited the kinetic energy carried by the beads to a level that was insufficient to cause cellular damage at every bead-bead or bead-cell wall collision, thus, increasing the specific energy demand for effective disruption. Increasing bead size also reduced the energy and disruption efficiency, for example, beads with a diameter of $1.5 \mathrm{~mm}$ required a specific energy of $>10,000 \mathrm{~kJ} / \mathrm{kg}$ DS to achieve $60 \%$ of the disruption obtained at $0.2 \mathrm{~mm}$. This represented an energy consumption almost an order of magnitude higher compared to the smaller bead size. Rai et al. [104] similarly reported that the specific energy required for maximum cell disruption (89\%) using $0.77 \mathrm{~mm}$ diameter beads was equivalent to $15,301 \mathrm{~kJ} / \mathrm{kg}$ DS.

The speed of agitation is another important parameter influencing the performance of milling, and the first-order rate constant $(k)$ additionally increases with agitation speed [105]. However, an optimal agitation speed is necessary from a practical point of view, since the total energy demand could become significant at higher agitation speeds compared to lower speeds. Suarez Garcia et al. [99] assessed the power consumption of a bead mill under several scenarios including running the mill empty, or with beads $(0.5 \mathrm{~mm}$, $65 \% \mathrm{v} / \mathrm{v}$ loading rate) and/or microalgae cells (concentration ranging $30-155 \mathrm{~g} / \mathrm{L}$ ). The power consumption over a period of 20 min showed an exponential increase, from $<50 \mathrm{~W}$ in all scenarios to $100-350 \mathrm{~W}$ as the agitation speed increased from 1500 to $5500 \mathrm{rpm}$, respectively. Similarly, the heat dissipation (mainly due to friction) also increased from 17.8 to $60.8 \%$ of the total power consumed. This was probably because the movement of the beads is more chaotic at higher agitation speeds, which forces the agitator to demand more power to keep a constant stirring speed in the chamber [99].

Cell Concentration: Postma et al. [95] investigated the effectiveness of a Dyno mill (filled with $1 \mathrm{~mm} \mathrm{ZrO}_{2}$ beads with $65 \% \mathrm{v} / \mathrm{v}$ loading rate) at disrupting microalgae cells of Chlorella vulgaris. The soluble protein yield after cell disruption was significantly influenced by the concentration of biomass fed into the unit, regardless of the agitation speed (ranging from 6 to $12 \mathrm{~m} / \mathrm{s}$ ). The highest yield (42\%) was obtained with the smallest biomass concentration ( $25 \mathrm{~g}$ dry weight $/ \mathrm{kg}$ ) and decreased by $25 \%$ as the biomass concentration increased to $145 \mathrm{~g}$ dry weight $/ \mathrm{kg}$. This was explained by the formation of insoluble protein aggregates at the high biomass concentration due to increased local protein concentrations, shear forces and interactions with other cellular substances/components. Furthermore, microbial cell suspensions with higher concentrations often show increased viscosity, and handling such material is practically limiting due to greater biomass losses and reduced mixing properties, compared to lower biomass concentrations [95].

Microbial Cell Type: Middelberg [106] indicated that bead milling is more effective for disrupting microorganisms with larger cells (e.g. yeast and fungi) compared to smaller 
cell types (e.g. bacteria, which are typically $1 / 10$ the size of yeast cells [98]), due to the enhanced collision frequency between beads and larger cells. Indeed, multiple passes of operation of bead milling are often required to provide a similar degree of disruption for bacteria cells compared with a single pass operation for yeast cells.

Furthermore, the strength of the cell wall and its resistance to shear forces/bead collisions varies between biomass materials, resulting in different disruption efficiencies and $k$ values. For example, higher shear stress may be required to achieve the complete destruction of bacterial cell walls, which contain a rigid peptidoglycan network, compared with yeast cell walls that are mainly composed of short and branched saccharide molecules (such as glucans and mannans) [106].

Advantages and Disadvantages Bead milling has several advantages for cell disruption and recovery of cellular materials, such as a continuous mode of operation, high disruption efficiency, simple biomass loading, and applicability to various types of biomass and scales [100]. However, the vigorous friction in the chamber converts a significant portion of the available energy into heat during the milling process. This can lead to inefficient energy transfer to individual cells [100] and also may require an intensive, energy-demanding cooling system to allow the recovery of functionally fragile products (e.g. enzymes) [107]. Moreover, continuous mode operation requires extra measures, such as sieving and centrifugation to separate the beads from the disrupted sludge cells. These additional process requirements may explain why milling has not been adopted as extensively for industrial enzyme recovery compared to sonication.

\section{Chemical Extractants}

\section{Cation Removal Agents}

Cation exchange resin (CER) [108, 109], ethylene diamine tetraacetic acid (EDTA) [110, 111], and sodium tripolyphosphate (STPP) [112] have been applied as chemical agents to extract both EPS and cellular enzymes from AS. The mechanism of enzyme extraction is similar for all of these chemical agents and involves removing multivalent cations from sludge EPS to disrupt AS flocs. Cations, such as: $\mathrm{Ca}^{2+}, \mathrm{Mg}^{2+}, \mathrm{Fe}^{3+}$ and $\mathrm{Al}^{3+}$, play a significant role in maintaining the structural stability of AS flocs by forming ionic bridges and stabilising proteins (which are usually negatively charged under neutral conditions due to ionization of carboxyl groups) and also small fractions of carbohydrate and nucleic acids $[113,114]$. EDTA and STPP are chelating agents and form complexes with metal ions, whereas CER is a polymer and acts as a cation exchange medium that binds with multivalent, bridging cations, to release EPS components into solution.

Chemical extractants damage cell membranes and eventually lead to cell lysis, but are much less aggressive compared to physical methods of cell disruption. For example, Frolund et al. [45] found that $90 \%$ of the extracellular enzyme, esterase, was rapidly released within $1 \mathrm{~h}$ when extracting microbial EPS with CER. By contrast, $<40 \%$ of the intracellular enzyme, dehydrogenase, was detected during this period; however, the majority of dehydrogenase was released by extending the treatment time up to $8 \mathrm{~h}$. The differences in the patterns of detection of these extra- and intracellular enzymes suggested minimal cell lysis occurred during the initial period of CER treatment. Therefore, potential advantages of chemical extractants are that they can: (1) specifically target the recovery of extracellular enzymes, and (2) reduce cell disintegration and contamination with intracellular enzymes or other cellular components.

As may be expected, the dose rate of a chemical extractant can significantly affect the extraction efficiency. Sheng et al. [115] used EDTA to extract EPS proteins from the bacteria Rhodopseudomonas acidophila. They found that EPS extraction increased markedly (from 29.9 to $84.3 \mathrm{mg} / \mathrm{g}$ dry cells) with the EDTA dose (from 0.8 to $2.8 \mathrm{~g} / \mathrm{g}$ dry cells). However, raising the dose further did not improve protein extraction, presumably because the maximum removal of divalent ions from EPS had been achieved. Similarly, Merrylin et al. [113] observed a stepwise improvement in EPS release, without cell lysis, with increasing EDTA dose up to $0.4 \%$ (equivalent to $0.71 \mathrm{~g} / \mathrm{g}$ VS of sludge), which gave the maximum EPS content of $38 \mathrm{mg}$ DS/L in the crude extract. Larger doses, $\geq 0.5 \%$ of EDTA (equivalent to $\geq 0.89 \mathrm{~g} / \mathrm{g}$ VS of sludge), had no further effect on EPS release, but increased cell lysis.

\section{Formaldehyde}

Formaldehyde (systematic name: methanal $\left(\mathrm{CH}_{2} \mathrm{O}\right)$ ) is the simplest aldehyde compound ( $\mathrm{R}-\mathrm{CHO})$ and is widely used in various industries as a common precursor for producing more complex compounds and materials (e.g. polyoxymethylene and phenol formaldehyde resins) [116]. It has also been used as a chemical agent for crude enzyme and EPS extraction (in combination with, or without sodium hydroxide $(\mathrm{NaOH})$ ) [40]. In aqueous solution, formaldehyde binds to macromolecules (e.g. proteins in EPS) by reacting with various functional groups [117]. Formaldehyde also reacts with amino, hydroxyl, carbonyl and sulfhydryl groups of proteins and nucleic acids of the cell membrane, forming cross-linked complexes. The addition of $\mathrm{NaOH}$ increases the $\mathrm{pH}$ of the mixture, dissociating the acidic groups in EPS and increasing the solubility of EPS in water. Comte et al. [118] found that a formaldehyde- $\mathrm{NaOH}$ process (involving 
the incubation of microbial cells from AS with $36.5 \%$ formaldehyde at $4{ }^{\circ} \mathrm{C}$ for $1 \mathrm{~h}$, followed by addition of $1 \mathrm{M}$ $\mathrm{NaOH}$ and incubation for a further for $3 \mathrm{~h}$ ) was more effective than EDTA and CER at extracting EPS from AS cells. For example, the EPS yield (dry weight of EPS/sludge DS expressed as \%) obtained for the different extractants: formaldehyde, EDTA and CER, was 47.0, 19.2 and 3.1\%, respectively. Similar results were also reported by Alasonat and Slaveykova [119] investigating different methods of EPS extraction from the bacterium, Sinorhizobium meliloti. In this case, an equivalent formaldehyde- $\mathrm{NaOH}$ process applied to a suspension culture of the bacteria increased the protein content in extracted EPS by 1.6-1.8 times compared to an EDTA extraction technique (2\% EDTA and incubation at $4{ }^{\circ} \mathrm{C}$ for $3 \mathrm{~h}$ ).

\section{Surfactants}

Surfactants (e.g. Triton X100 [120] and Tween 20 [74]) are often used as additives to enhance the efficiency of EPS and enzyme extraction from AS cells. For example, Triton $\mathrm{X} 100$ (TX100) is a non-ionic surfactant that is widely used in cell lysis protocols. It can permeabilise microbial cell membranes and consequently improve the release of cellular proteins and enzymes [121]. Karn and Kumar [122] suggested the addition of TX100 weakens the hydrophobic interaction between enzymes and the sludge floc components they attach to, facilitating the release of extracellular enzymes from the cell by shearing forces induced by simple continuous stirring.

However, TX100 can have both positive and negative effects on extraction performance, depending on the concentration used and type of enzyme. For example, Nabarlatz et al. [29] combined TX100 addition with sonication treatment to recover protease and lipase from AS. They found that, under the equivalent sonication treatment $\left(8 \mathrm{~W} / \mathrm{cm}^{2}\right.$ power intensity, $20 \mathrm{kHz}$ frequency and $10 \mathrm{~min}$ duration), protease extraction was significantly improved with increasing TX100 concentration, achieving the maximum enzyme activity (52.9 U/g VS) at $2 \%$ v/v TX100. However, lipase extraction followed a different pattern and, in this case, the maximum activity (11 U/g VS) was obtained with $0.5-1 \%$ $\mathrm{v} / \mathrm{v}$ TX100 and increasing the TX100 concentration to $>1 \%$ $\mathrm{v} / \mathrm{v}$ reduced the enzyme activity. Other researchers (e.g. [28, 43]) also report the greater sensitivity of lipase to TX100 concentration compared to protease.

Bio-surfactants offer a novel alternative to standard chemical surfactants for enzyme recovery from AS. For example, Sethupathy and Sivashanmugam [123] used rhamnolipid (a bio-surfactant produced by the bacterial strain, Pseudomonas pachastrellae) in combination with sonication to extract a crude compound enzyme product from AS. The optimum extraction conditions were obtained with $2 \%$ $\mathrm{v} / \mathrm{v}$ of rhamnolipid and ultrasound treatment at $100 \mathrm{~W}$ for $15 \mathrm{~min}$, providing a specific energy intensity of $30,456 \mathrm{~kJ} /$ $\mathrm{kg}$ DS. The maximum activity of protease, $\alpha$-amylase, cellulase, lipase and $\alpha$-glucosidase in the crude product was 42 , $52,34,24$, and $11 \mathrm{U} / \mathrm{g} \mathrm{VS}$, respectively. This was comparable with the extraction efficiencies of hydrolytic enzymes obtained with the standard chemical surfactant, TX100, at $1 \% \mathrm{v} / \mathrm{v}$ combined with sonication treatment $(75 \mathrm{~W}$ ultrasound energy, 10 min duration and $27,027 \mathrm{~kJ} / \mathrm{kg}$ DS specific energy) [112].

\section{Factors Influencing Enzyme Extraction from Activated Sludge}

\section{Enzyme Location in Sludge Flocs}

As extracellular enzymes are located in different EPS fractions of AS flocs, the degree of floc and cell disruption required to harvest them depends on whether they are associated with LB-EPS or TB-EPS, or whether they are attached to cell walls. Thus, enzymes located in the EPS fraction (so called "exo-enzymes") can be readily extracted by harvesting the EPS. In contrast, enzymes that are closely attached to the cell surface ("ecto-enzymes") may remain after removing EPS from the cell [42] and, therefore, require more physically or chemically aggressive methods for their effective extraction. Cadoret et al. [42] suggested that, in general, the distribution of enzymes between the exo- and ecto- pools was approximately in the proportions: 5-44\% and $56-95 \%$, respectively. Different exo-enzymes are distributed between the LB-EPS or TB-EPS fractions and, consequently, also vary in extractability [124]. Thus, LB-EPS can be readily separated by shearing detachment from sludge flocs from exposure to turbulence within the extraction solution, whereas TB-EPS is less affected by physical agitation because it exhibits stronger hydrophobic properties.

Yu et al. [40] investigated the effectiveness of different methods at extracting crude hydrolytic enzymes from AS. The maximum amount of protease (an ecto-enzyme) obtained by formaldehyde extraction (AS was incubated with $36.5 \%$ formaldehyde at $4{ }^{\circ} \mathrm{C}$ for $1 \mathrm{~h}$ ) from both LBEPS and TB-EPS was $2.3 \mathrm{U} / \mathrm{g}$ VS. However, more than $60 \%$ of the total protease was still closely associated with the cell surface after EPS removal. In contrast, up to 84 and $79 \%$ of the exo-enzymes: $\alpha$-amylase and $\alpha$-glucosidase, were extracted, respectively, by a formaldehyde- $\mathrm{NaOH}$ process (incubation with $36.5 \%$ formaldehyde for $1 \mathrm{~h}$, followed by addition of $1 \mathrm{M} \mathrm{NaOH}$ and incubation for a further $3 \mathrm{~h}$ ) and sonication ( $120 \mathrm{~W}, 40 \mathrm{kHz}, 2 \mathrm{~min})$. Gessesse et al. [28] also found that extracting protease was more difficult than lipase (another example of an exo-enzyme present in LB-EPS [24]). They observed the maximum protease activity in the crude extract after extraction treatment for $1 \mathrm{~h}(60-70 \mathrm{~g} / \mathrm{g}$ 
VS of CER addition, in the presence of $0.1 \%$ TX100). In contrast, maximum lipase activity occurred after $10 \mathrm{~min}$ under equivalent conditions.

\section{Upstream Wastewater Management}

Microorganisms react dynamically to changes in environmental conditions within the aquatic ecosystem of the biological wastewater treatment process, including: $\mathrm{pH}$, temperature, organic substrates in the influent, the hydraulic regime and presence of toxic substances/enzyme inhibitors [125]. These conditions determine the microbial physiology and, therefore, the nature of enzyme secretion. The major factors that potentially influence the types and properties of hydrolytic enzymes in AS include:

Wastewater Composition The enzyme activity profile of AS is strongly affected by the composition of the influent wastewater. For example, Nybroe et al. [52] found that addition of readily degradable starch to wastewater increased the activity of $\alpha$-glucosidase in sludge flocs $(0.2-0.4 \mu \mathrm{mol} / \mathrm{mg}$ $\mathrm{VS} / \mathrm{h}$ ) compared to the control group without starch addition $(<0.1 \mu \mathrm{mol} / \mathrm{mg} \mathrm{VS} / \mathrm{h})$. Li and Chrost [126] compared the activities of four extracellular enzymes, including: leucine aminopeptidase, $\beta$-glucosidase, alkaline phosphatase and lipase, in communal, dairy and petroleum wastewater treatment systems. The AS from each system showed a wide range of activities for each enzyme type investigated, equivalent to: $27.8-41.5,32.9-57.8,31.0-47.0$ and 86.0 $161.2 \mu \mathrm{mol} / \mathrm{L} / \mathrm{h}$, respectively. The relative activity of each enzyme was largely related to the composition of the influent wastewater and the abundance of particular substrates. Thus, lipase activity was highest, and leucine aminopeptidase and $\beta$-glucosidase activities were lowest, for AS from petroleum wastewater, which was richer in lipids, but had reduced protein and carbohydrate contents, compared to the other wastewater types. Yu et al. [127] investigated the activity of extracellular enzymes in AS samples collected from 14 WWTPs. For all WWTPs, activities of $\alpha$-amylase and $\alpha$-glucosidase were significantly correlated with the polysaccharide concentration in the wastewater (Pearson's correlation coefficients were 0.79 and 0.76 , respectively). Similarly, protease activity was significantly correlated with the protein concentration for WWTPs treating wastewater with a high-protein content (Pearson's correlation coefficient $=0.79$ ).

Furthermore, anthropogenic chemical compounds (e.g. organic micropollutants) in wastewater can lead to the expression of specific enzyme types (so-called "inducible enzymes") by microbial cells in AS. For example, Liu et al. [128] found that the presence of anilines, a group of environmental pollutants associated with the manufacture of dye materials and herbicides, induced the expression of aniline dioxygenase (1.094 U/mg protein) and catechol 2,3-dioxygenase (5.224 U/mg protein) by the bacteria, Delftia sp., isolated from municipal AS. Similarly, Sphingomonas sp. Y2, isolated by Bai et al. [129] from sewage sludge, produced inducible enzymes and degraded $99.2 \%$ of the surfactant, nonylphenol polyethoxylate, which is an environmentally active anthropogenic compound with oestrogenic and mutagenic properties.

Inducible enzymes can also be produced by the addition of secondary materials to AS. Hao and Jahng [130] found that a biodrying process was accelerated by adding spent coffee grounds as a bulking agent to dewatered AS, which increased the water removal rate to $81 \%$ in 8 days, compared to $65 \%$ removal in the control treatment without coffee grounds. The improved drying rate was not only explained by the better structural conditions, which increased microbial biodrying activity, but also because the abundance of mannan (a plant storage polysaccharide that constitutes more than $50 \%$ of total hemicellulose) in coffee grounds induced the significant production of mannanase. Indeed, the specific activity of mannanase was undetectable in the control, but increased to approximately $3100 \mu \mathrm{g} / \mathrm{min} / \mathrm{g}$ DS by the $2 \mathrm{nd}$ day of biodrying with coffee grounds. The large amount of induced mannanase interacted synergistically with protease, amylase and cellulase, to accelerate the aerobic biodegradation of protein and lignocellulose, thus increasing heat generation and the associated biodrying rate.

These various examples illustrate the potential flexibility and capacity of AS, and biological waste treatment systems in general, to produce a wide variety of commercially important enzymes. The research suggests the addition of particular organic chemical substrates, or secondary materials, such as industrial organic wastes rich in certain substances, to AS under controlled conditions as "stimulating agents" would offer a practically feasible and viable approach to induce the production of an array of high value, specific, novel enzyme products.

Sludge Age Sludge age represents the average residence time of active microorganisms in a biological wastewater treatment reactor; it is one of the main parameters influencing the operation of the AS process and has a significant impact on the treatment performance of a WWTP [131]. A sludge age of 3-6 days is typical for WWTP where only removal of carbonaceous matter in wastewater is necessary. However, most WWTP must also remove ammonia $\left(\mathrm{NH}_{3}\right)$, which is an extremely harmful pollutant of natural water systems, and this is achieved concomitantly with organic carbon mineralisation in the AS process through biological oxidation by nitrifying bacteria. Nitrifiers are relative slow growing chemoautotrophic bacteria, therefore, a longer sludge age, typically up to 18 days, is necessary, depending on the ambient temperature and influent composition, 
to main nitrification activity [18]. Sludge age can also influence the activity of hydrolytic enzymes in AS. For example, sludge hydrolase activity increased by a factor of two when the sludge age was extended from 6 to 14 days [132]. This may be explained because, at longer sludge ages, dead microbial biomass may be utilised as an energy source by the remaining viable cells. Consequently, the increased availability of organic substrates, mainly in the form of rigid cellular components such as gelatin, stimulated the production of hydrolytic enzymes in the viable microbial fraction.

Activated Sludge Reactor Type In general, biological wastewater treatment processes can be classified into suspended growth systems (such as the conventional AS process) and attached growth systems (which include trickling filters, moving bed biofilm reactors, membrane biofilm reactors, etc.). In conventional AS, sludge flocs, which are agglomerations of microorganisms that are flocculated together and embedded in EPS, are suspended by physical agitation within the treatment process. By contrast, attached growth systems develop a fixed biofilm of microorganisms that is attached to a solid support medium. Therefore, attached growth systems typically have longer sludge retention times and a higher diversity of microorganisms than conventional AS processes, which also enables them to perform more efficiently at higher organic loading rate (OLR) [133]. This behaviour also has implications for enzyme production since increasing OLR stimulates the expression of extracellular hydrolytic enzymes in microbial cells. For example, Hassard et al. [134] found the activity of amino-peptidase, $\alpha$-glucosidase and phosphatase increased by $4.6,13.5$ and 6.3 times, respectively, in a rotating biofilm reactor (a semisubmerged attached growth reactor with a rotating support material of high porosity mesh plates) compared to a conventional AS system. However, excess OLR can limit enzyme expression, because diffusion of compounds of large molecular weight and electron acceptors may decline under high OLR conditions [134].

\section{Effect of Sampling Location on Enzyme Extraction from Activated Sludge}

In the AS process, settled sewage from primary wastewater sedimentation is combined with returned AS (and is referred to as mixed liquor) to treat non-settleable, soluble and colloidal pollutants. Microbial activity increases and is typically ten times greater at the front of the plug-flow AS process in response to the availability of readily degradable substrates in the influent wastewater compared to the discharge point, where only biologically recalcitrant materials are present [18]. Indeed, Liu and Smith [23] found that dehydrogenase activity (an intracellular oxidoreductase that is a general indicator of microbial activity) increased from the inlet to a maximum value (5 U/g VS) at a central position in the aeration tank and subsequently decreased by approximately $35 \%$ at the discharge end of the process. In contrast, the activities of extracellular hydrolytic enzymes in AS extracts sampled at different positions along the aeration tank, and from the thickening belt after secondary sedimentation of the AS (this fraction is usually diverted to a sludge treatment process, such as AD), were relatively consistent. The maximum activities of protease, amylase and cellulase measured in crude AS extracts were: 8.2, 52.2 and $9.9 \mathrm{U} / \mathrm{g}$ VS, respectively [23]. Thus, hydrolytic enzymes involved in bacterial carbon catabolism are active not only when organic substrates are in ample supply at the inlet to the AS process, but also when they are exhausted [135]. This behaviour may be related to an ecological survival strategy adopted by floc forming bacteria to nutrient depleted conditions and to the stability of hydrolytic enzymes in the EPS fraction. Maintaining a high density of stable hydrolytic enzymes in floc EPS allows the rapid hydrolysis and assimilation of new substrates immediately they become available without the need to divert resources to, or for a time delay in, enzyme synthesis. The practical consequence of this behaviour for commercial enzyme extraction from AS is that optimum yields of hydrolytic enzymes can be obtained from the waste AS stream collected following standard operating practice, without any special intervention or alternative management of the biological wastewater treatment process.

\section{Enzyme Purification and Stabilisation}

\section{Purification}

Crude enzyme extracts from AS inevitably contain a large amount of water, and their stability in storage and suitability for industrial application is relatively limited. The presence of inhibitory substances, co-extracted from the sludge biomass, can reduce the activity of crude enzyme mixtures, however, whilst purification can increase stability and enzymic specificity, it can also cause performance losses to a certain extent compared to the crude enzyme extract. Nevertheless, the benefits of consolidating and purifying enzymes to upgrade crude AS extracts

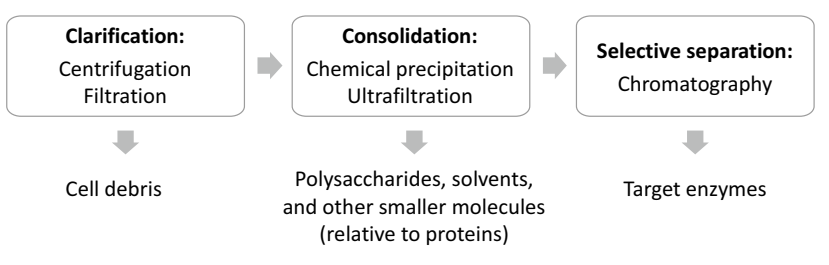

Fig. 5 Stepwise procedure for purification of enzymes 
will further facilitate the development of marketable, high value commercial products from this secondary biomass source.

Purification of enzymes is achieved following a multistep series of processes (Fig. 5). The first step is clarification of the crude extract to remove remaining cell debris. The sedimentation rate of a bacterial cell with a diameter of $0.5 \mathrm{~mm}$ is less than $1 \mathrm{~mm} / \mathrm{h} \mathrm{[15].} \mathrm{Therefore,}$ rapid separation can be achieved by centrifugation and filtration, to separate soluble proteins (including enzymes) from organelle-sequestered proteins and retain them in the supernatant or filtrate [136].

The total volume of the clarified enzyme solution is generally very large, but the concentration of enzymes is relatively low. However, the enzyme concentration in the solution can be consolidated by chemical precipitation. Enzymes are complex protein molecules possessing both ionic and hydrophobic groups and are readily susceptible to precipitation by a number of different reagents including: (1) neutral salts (followed by a dialysis step for salt removal), e.g. ammonium sulphate, which change the electrostatic forces responsible for the solubility by acting on the water molecules surrounding the protein; (2) organic solvents, e.g. acetone, ethanol and butanol, which reduce the dielectric constant of the water solution, causing aggregation of proteins; and (3) polymers, e.g. polyethylenimines and polyethylene glycols, which precipitate proteins by inducing steric exclusion effects [137]. Alternatively, consolidation can be achieved by ultrafiltration (e.g. [138]), by separating large enzyme molecules from smaller solvent molecules through a semipermeable membrane (pore size ranging from 0.008 to $0.2 \mu \mathrm{m}$ [18]).

Purification treatment of crude AS extracts generally leads to a diminution of enzyme activity (on an equivalent volumetric base) to some extent for several reasons [139]. Jung et al. [140] observed a reduction in protease activity, equivalent to approximately $30 \%$, following precipitation of a crude enzyme extract from disrupted AS with 40-50\% saturated ammonium sulphate, compared to the original extract, and explained that this was probably due to the loss of protein content (approximately $36.2 \%$ protein) during chemical precipitation. Nabarlatz et al. [54] purified lipase obtained from AS by precipitation with $40 \%$ saturated ammonium sulphate and dialysis (12-14 kDa), and obtained an activity recovery rate for each step equivalent to $74 \%$ and $45 \%$, respectively. $\mathrm{Ni}$ et al. [56] extracted a crude enzyme product from AS using 1\% TX100 and sonication treatment, followed by precipitation in $80 \%$ acetone and vacuum drying at $40{ }^{\circ} \mathrm{C}$, and found that $47,45,34$, and $32 \%$ of the activity in the original crude enzyme extract of collagenase, lipase, amylase, and cellulase, respectively, was preserved in the final dried enzyme product.
Higher degrees of purification can be obtained by applying chromatographic techniques after the basic clarification and consolidation stages [141], and this is usually necessary for analytical or medical applications. Enzyme molecules can be selectively separated chromatographically based on their size and shape, total charge, hydrophobic groups present on the surface, and binding capacity with the stationary phase [142]. For example, Erat et al. [143] purified glutathione reductase extracted from chicken liver and precipitated with ammonium sulphate, using Sepharose affinity chromatography, and Sephadex gel filtration chromatography. The enzyme was purified 1714-fold relative to the original crude enzyme solution, and the specific activity of the final enzyme product was $120 \mathrm{U} / \mathrm{mg}$ protein. Ion-exchange chromatography for enzyme purification is also frequently reported [144-146].

In summary, the purification/consolidation steps necessary to develop commercial products from AS may reduce the enzyme activity by $30-70 \%$ compared to the original crude extract. However, this is the case with all bioenzyme recovery/purification systems from microbial biomass [15] and, in practice, only small quantities of enzymes are used to catalyse process reactions, so it is unlikely that this is a significant barrier to the development of commercially viable, industrial enzyme products from AS produced by biological wastewater treatment. Indeed, consolidation and purification would increase the flexibility and range of industrial enduses and marketability of AS enzyme products.

\section{Stabilisation/Immobilisation}

Free enzymes often show poor storage and operational stability, they are readily inactivated and are difficult to recycle and reuse, which limits their large scale commercial application [147]. Immobilisation of free enzymes is a promising approach to overcome these drawbacks, by enhancing mechanical strength, increasing resistance to denaturation and facilitating recycling of the enzyme catalyst within a reaction system [148, 149].

Conventional enzyme immobilisation is by chemical or physical binding to an inert carrier (e.g. sephorose, zeolites, silica, agarose, alginate, polyacrylamide, hollow fibres and acrylic resins) by adsorption, entrapment or encapsulation [150]. However, the carrier introduces a large amount of non-catalytic material, typically representing $90-99 \%$ of the total mass of the enzyme product [151], which significantly dilutes the enzyme activity. Recently, carrier-free immobilisation, by intermolecular cross-linking between adjacent enzyme molecules (shown in Fig. 6), has emerged as an alternative method to conventional carrier-bound enzyme immobilisation [152-154]. This technique combines purification and stabilisation into a single step, and can be performed directly on crude enzyme extracts, such 


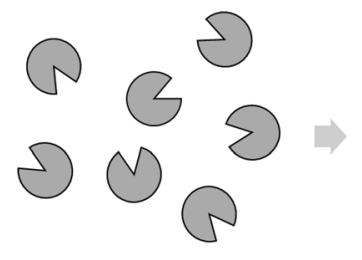

a

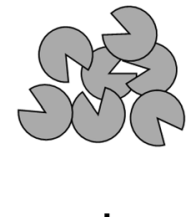

b

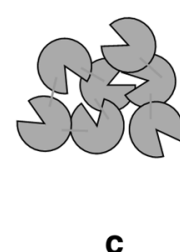

C

Fig. 6 Enzyme immobilisation by cross-linking: a free enzyme in solution, $\mathbf{b}$ chemical precipitation of enzyme, $\mathbf{c}$ cross-linking of the precipitated enzyme (represented by lines)

as those obtained from AS [155]. Furthermore, immobilising enzymes by cross-linking to the surface of a membrane or micro-reactor for use within a continuous reaction process [156] offers significant potential opportunities and is an exciting area for future research and development. For instance, Barber et al. [157] recently proposed that oxidoreductase enzymes cross-linked with flexible spacers (e.g. polyethylene glycol) could provide an effective approach to organic micropollutant degradation in municipal wastewater treatment.

\section{Potential Applications of Recovered Enzymes from Activated Sludge}

\section{Wastewater Treatment}

Jung et al. [140] extracted compound enzymes from laboratory-cultured AS by milling disruption of sludge flocs and ammonium sulphate precipitation, followed by re-suspension. The compound enzyme product (containing protease at $5.4 \mathrm{U} / \mathrm{mL}$ ) was mixed with an artificial milk wastewater at a volume ratio of $1: 1$, and rapidly hydrolysed the protein content within $2 \mathrm{~h}$, releasing the degradation product, tyrosine (a main constituent amino acid of milk protein), at a yield of $103 \mu \mathrm{g} / \mathrm{mg}$ protein. The results therefore demonstrated the potential application of AS enzymes for the treatment of waste streams high in protein and lipid content, such as diary wastewater.

Damasceno et al. [158] dosed crude, solid, lipase-rich compound enzymes, obtained from the solid-state fermentation of agro-industrial wastes by Penicillium restrictum, into a wastewater reactor treating an artificial, high-fat dairy wastewater (with $1200 \mathrm{mg}$ oil and grease per L) and found the removals of both chemical oxygen demand (COD) and turbidity were improved. Dosing the enzyme at a rate of $0.1 \% \mathrm{w} / \mathrm{v}$ increased the overall COD removal from $83 \%$ (in the control) to $90 \%$, and the effluent turbidity decreased by $50 \%$ compared to the control, without enzyme dosing.

Mackul'ak et al. [159] applied an enzymatic pretreatment unit (using a commercial mixture of various redox enzymes, transferases and hydrolases, with an enzyme activity equivalent to $4881 \mathrm{U} / \mathrm{mL}$, dosed at $2 \mathrm{mg} / \mathrm{L}$, and a treatment duration of $60 \mathrm{~min}$ ) to an industrial paintshop wastewater with a high content of organic nitrogen $(\mathrm{COD}=5100 \mathrm{mg} / \mathrm{L}$, total nitrogen $=184 \mathrm{mg} / \mathrm{L}$ ), followed by a $24 \mathrm{~h}$ lab-scale AS process. The COD and total nitrogen content of the treated wastewater decreased to 200 and $20 \mathrm{mg} / \mathrm{L}$, respectively, compared to 840 and $45 \mathrm{mg} / \mathrm{L}$, respectively, for the control without enzymatic pretreatment.

Mobarak-Qamsari et al. [160] obtained a crude enzyme extract from Pseudomonas aeruginosa KM110 (a bacterium strain isolated from wastewater collected from an oil processing plant), with lipase activity $=0.3 \mathrm{U} / \mathrm{mL}$. The enzyme extract was applied as a hydrolysis pretreatment to synthetic dairy wastewater (dose rate $=10 \% \mathrm{v} / \mathrm{v}$ and incubation at $45^{\circ} \mathrm{C}$ for $48 \mathrm{~h}$ ), followed by anaerobic wastewater treatment $\left(37^{\circ} \mathrm{C}\right.$, retention time $=13$ days $)$. Enzymatic prehydrolysis significantly increased the COD removal and biogas output by approximately 1.5 and 2 times, to $90 \%$ and $4710 \mathrm{~mL} / \mathrm{L}$ wastewater, respectively, compared to the control.

\section{Pre-treatment of Waste for Anaerobic Digestion}

Anaerobic digestion is the preferred treatment method for a wide variety of municipal, industrial and agricultural organic waste materials, and particularly those with high moisture contents, as it is effective at stabilising organic matter, reducing odour nuisance and potential human pathogens, and produces a biogas rich in methane that is a valuable renewable energy source [21, 161]. However, the initial hydrolysis step of $\mathrm{AD}$ is often rate-limiting to the treatment of complex organic substrates, such as sewage sludge $[162,163]$. Enzymatic pretreatment can enhance anaerobic digestibility of sewage sludge by increasing lysis of microbial cells and the release of protein and carbohydrate substrates from sludge flocs, and also by accelerating the biodegradation of recalcitrant materials, such as humic and fulvic acid-like substances [164].

Arun and Sivashanmugam [165] used a crude compound enzyme extract from the fermentation of fruit peel waste (pineapple and orange) to solubilise the polymeric organic compounds in waste AS. The sludge was incubated with enzymes at $35{ }^{\circ} \mathrm{C}$ and $\mathrm{pH} 7$ for $60 \mathrm{~h}$ and the VS reduction and COD solubilisation following enzymatic treatment were approximately $22 \%$ and $25 \%$, respectively, compared to $5 \%$ and $6 \%$, respectively, for the control treatment (without enzyme addition).

Yin et al. [166] applied a fungal mash (rich in hydrolytic enzymes) to pretreat AS, mixed with food waste, prior to AD. The pretreatment produced a soluble COD equivalent to $7.65 \mathrm{~g} / \mathrm{L}$ within $24 \mathrm{~h}$, which was approximately 1.7 times 
larger compared to the control, and the biomethane yield from $\mathrm{AD}$ of pretreated sludge increased 2.5 times compared to AS without pretreatment.

Bonilla et al. [167] pretreated pulp and paper biosludge with protease extracted from Bacillus licheniformis (ratio of protein/biosludge DS, 1:100) for AD and measured the effects on the biogas yield. The pretreatment enhanced the anaerobic digestibility of the sludge, increasing the specific biogas yield (measured in a 62-day biomethane potential test) by up to $26 \%$ to approximately $160 \mathrm{~mL} / \mathrm{g} \mathrm{COD} \mathrm{com-}$ pared to the control supplied with inactivated enzyme, which produced approximately $130 \mathrm{~mL} / \mathrm{g}$ COD of biogas.

Bahreini et al. [168] dosed a commercial enzyme product (containing cellulase and xylanase, with $20 \%$ active protein content) into primary sludge at a rate of $1 \%$ of the DS in the feed, prior to fermentation at $35^{\circ} \mathrm{C}$ for 2 days. The specific soluble COD and VFA yields during the fermentation process were $316 \mathrm{mg} / \mathrm{g}$ VS and $201 \mathrm{mg}$ COD/g VS, respectively, for the control group, and increased with enzymatic treatment by $68 \%$ and $35 \%$ to $532 \mathrm{mg} / \mathrm{g}$ VS and $272 \mathrm{mg} \mathrm{COD} / \mathrm{g}$ VS, respectively.

\section{Organic Micropollutant Degradation}

Compound enzymes extracted from AS can also significantly improve the biodegradation of organic micropollutants in municipal wastewater treatment. For example, crude, cell-free compound enzymes from AS degraded the pharmaceutical compounds: acetaminophen (an analgesic), $\mathrm{N}$-acetyl-sulfamethoxazole (an antibiotic), atenolol (a beta blocker) and bezafibrate (a lipid-lowering agent), with average removal efficiencies of $85,59,26$ and $20 \%$, respectively, compared to the control with heat deactivated enzymes, which showed no removal [55]. The majority of enzymes involved in the degradation of organic pollutants are hydrolytic (e.g. phosphatase, galactosidase and glucuronidase), and these are abundant in AS, but, other, minor nonhydrolase enzymes, such as oxidoreductase, have a strong and critical influence on pollutant destruction and may also be extracted, or inducible, in AS [55] (also see Sect. 3.4.2).

Zhou et al. [169] investigated the effects of enzyme addition on the removal of four pharmaceutically active compounds during sewage sludge $\mathrm{AD}$. The pharmaceutical compounds included: clofibric acid (a lipid regulating agent), triclosan (a broad-spectrum antibacterial agent), diclofenac (an anti-inflammatory painkiller) and carbamazepine (an epilepsy drug) and each compound was added to raw sewage sludge at a concentration of $5 \mu \mathrm{g} / \mathrm{L}$. Different enzymes were mixed with sludge, including: papain (a proteolytic enzyme extracted from the papaya plant), lysozymes or cellulase, at dose rates of $30 \mathrm{mg} / \mathrm{g}$ DS, prior to mesophilic $\mathrm{AD}\left(35 \pm 2{ }^{\circ} \mathrm{C}\right.$ and solids retention time $=15$ days). The effects of enzyme dosing on the removal rates of the target pharmaceuticals varied depending on the type of enzyme and the specific compound type. In general, triclosan and carbamazepine were the most susceptible to enzymatic degradation, and cellulase was the least effective enzyme at organic micropollutant removal. Dosing with papain and lysozymes increased the removal of triclosan to 60 and $82 \%$, respectively, compared to $50 \%$ for the control treatment, and carbamazepine removal increased from $51 \%$ in the control to 64 and $58 \%$ by papain and cellulase addition, respectively. However, enzymatic treatment had no positive effect on the concentrations of clofibric acid or diclofenac and the largest removals of these compounds obtained with lysozyme dosing were 53\% and $58 \%$, respectively, compared to $61 \%$ and $60 \%$, respectively, in the control condition). Sonication treatment of the sludge $(20 \mathrm{kHz}$, power density at $0.05 \mathrm{~W} / \mathrm{mL}$ for $30 \mathrm{~min})$ significantly improved contaminant removal, by increasing the accessibility and biodegradation of organic pollutants by AD.

Therefore, Zhou et al. [170] proposed an integrated AD system, comprising of both hydrolytic enzyme dosing and pretreatment with ultrasound. Lysozymes and papain, which gave the best overall removal performance in the previous study, were mixed at a mass ratio of 1:1 and added to sludge at a rate of $30 \mathrm{mg} / \mathrm{g}$ DS prior to sonication and mesophilic $\mathrm{AD}$ (solids retention time $=15$ days). In this case, the micropollutants were dosed into the sludge at a higher rate equivalent to $7.5 \mu \mathrm{g} / \mathrm{L}$. Enzyme dosing also showed variable effects in the integrated system, however, a comparison with sonication without enzyme addition was not possible because this treatment was not included in the experimental design. Nonetheless, comparison with the earlier results [169] suggested the degradation of clofibric acid and carbamazepine was increased to 77 and $68 \%$, respectively, with combined enzyme dosing and sonication, compared to ultrasound alone (68 and 63\%, respectively [169]). On the same basis, there was little or no change in the removal of triclosan in the integrated system (69\%), compared to sonication alone (73\% [169]), and diclofenac degradation declined with enzyme dosing to $47 \%$ compared to $72 \%$ with ultrasound alone [169]. Increasing the digestion temperature of the integrated system to the thermophilic range $\left(55 \pm 2{ }^{\circ} \mathrm{C}\right)$, had no effect on diclofenac degradation (48\%) compared to mesophilic conditions $(47 \%)$, but removals of the other compounds decreased (71, 65 and $51 \%$ for clofibric acid, triclosan and carbamazepine, respectively) relative to mesophilic temperatures [170]. Thus, enzyme dosing had variable effects on the degradability of pharmaceutical compounds during $\mathrm{AD}$ of sewage sludge and this may be explained because: (1) enzymes demonstrate a high degree of specificity at cleaving chemical bonds of available substrates [171], (2) free enzymes may be vulnerable to and be inactivated by the $\mathrm{AD}$ environment, and (3) ultrasound exposure may damage the enzyme structure at thermophilic temperatures, causing the 
breakage of essential bonds at active sites (e.g. the disulfide bonds of lysozyme [172]).

Thus, specific enzymes may be required to degrade particular, unique contaminant compounds, and general hydrolytic enzymes, similar to those supplied by Zhou et al. $[169,170]$, may not be effective at removing all types of organic pollutant. Thus, the general hydrolytic enzymes extracted from AS will have variable effects on degrading a broad range of organic contaminants, but specific inducible enzymes can also be expressed to target the degradation of particular micropollutant compounds (Sect. 3.4.2). The sensitivity of free enzymes to treatment process conditions can also be reduced to enhance the longevity of activity by preparing stabilised/immobilised formulations (Sect. 4.2), Furthermore, the operational conditions (including temperature and reaction time) need to be optimised to facilitate the enzymatic hydrolysis treatment of organic micropollutants.

\section{Biofuel Production}

Selvakumar and Sivashanmugam [173] produced lipase from the anaerobic fermentation of organic waste, including: pomegranate, orange and pineapple fruit peels, followed by ammonium sulphate precipitation of the crude enzyme solution. The partially purified lipase $(56.5 \mathrm{U} / \mathrm{mL})$ was used as the catalyst for biodiesel production from yeast lipid. Under optimum conditions for lipase-catalysed transesterification (6.4 methanol/oil molar ratio, 20\% enzyme concentration, $35^{\circ} \mathrm{C}$ and $16 \mathrm{~h}$ treatment time), $97 \%$ of the original lipid source was transformed into biodiesel.

\section{Other Applications}

In addition to the cases mentioned above, recovered compound enzymes from secondary materials, such as AS, have potential applications in many other areas, for example:

\section{Leather Industry}

Abu Yazid et al. [174] produced an alkaline protease from the fermentation of hair waste, followed by partial purification of the crude enzyme solution using ultrafiltration and lyophilisation techniques. The effectiveness of the lyophilised enzymes at dehairing high pigmentation cowhides was examined by incubating sections of the cowhide with the enzyme for $24 \mathrm{~h}$, supplied at dose rates of $7556-9373 \mathrm{U} / \mathrm{cm}^{2}$. The performance of enzymatic dehairing was similar to a standard chemical treatment $(22 \mathrm{~h}$ soaking with sodium carbonate and a non-ionic surfactant for $22 \mathrm{~h}$, followed by reaction with calcium hydroxide for $1 \mathrm{~h}$ and sodium hydrosulphide for $30 \mathrm{~min}$ ) with a relative effectiveness of $90-95 \%$ compared to the chemical method. This study emphasised the significant potential of using enzymatic treatments as alternatives to chemical dehairing in the leather industry.

\section{Detergent Additives}

Purified proteases, amylases, lipase and cellulase are used as biodegradable, non-toxic additives to detergents to improve the effectiveness of stain removal from fabrics, without damaging the textile quality $[175,176]$. A major advantage of using enzymes in bulk detergent formulations is that they do not have harmful residues and, therefore, the environmental loading of synthetic chemicals from large scale detergent use can be reduced [176].

Zhang et al. [177] investigated the washing performance of several phosphate and non-phosphate detergents that were reformulated by adding alkali protease $(280 \mathrm{U} / \mathrm{mg})$ and/or amylase $(300 \mathrm{U} / \mathrm{mg})$. They found that the efficiency of stain removal was marginally increased with the addition of mixed enzymes compared to single enzymes, probably due to a synergistic reaction between protease and amylase. For example, the stain removal from a polyester/cotton fabric soiled with blood, milk and ink was $28 \%$ for protease addition $(0.5 \% \mathrm{w} / \mathrm{w})$ alone and this increased to $32 \%$ for the combined enzymatic treatment (protease: amylase $=1: 1,0.5 \% \mathrm{w} / \mathrm{w}$ dosage for each enzyme).

Some microorganisms in sludge are naturally able to produce enzymes that can remain active under the harsh conditions that are usually applied during detergent use (such as high temperature, alkaline $\mathrm{pH}$ and high salt concentration [178]). For example, El Hadj-Ali et al. [179] found that a thermostable, alkaline, serine-protease, produced by a bacterium, isolated from fishery sewage sludge (identified as Bacillus licheniformis NH1), could maintain $93 \%$ of its initial activity after incubation at $40{ }^{\circ} \mathrm{C}$ for $60 \mathrm{~min}$ in the presence of commercial laundry detergents $(7 \mathrm{mg} / \mathrm{mL})$. This suggested that the protease derived from secondary waste biomass may be suitable as an effective enzyme additive in detergent manufacture. Stabilised enzymes may also be suitable for use in detergent formulation. For example, Soleimani et al. [180] formulated a detergent powder containing $0.1 \%$ of $\alpha$-amylase, either as free enzyme or in immobilised form on silica nanoparticles, and examined the effect on the removal of starch stains from cotton fabrics, compared to the same formulation, but without enzyme addition. The presence of immobilised or free $\alpha$-amylase increased the cleaning efficiency (measured as the difference in the reflectance light intensity (\%) between washed and unwashed fabric, at a wavelength of $460 \mathrm{~nm}$ ) by approximately 2.3 and 1.5 times, respectively, compared to the control. 


\section{Animal Feed}

Increasing the digestibility and nutritional value of animal feeds (e.g. for pig and poultry production) is an area of expanding interest for the utilisation and application of compound enzymes [8]. The digestive systems of pigs and poultry tend to lack certain important enzymes that are necessary to break down complex organic substrates (such as barley, rye and oats) [181]. The use of endolytic enzymes as supplementary ingredients in animal feed formulations can effectively degrade cell wall polysaccharides in the feed and reduce the viscosity of the intestinal contents, resulting in improved digestion, absorption and nutritive value of feed stuffs $[182,183]$.

Kalmendal and Tauson [184] investigated the effect of mixed xylanase and protease (alone and/or in combination) supplied to broiler chickens fed a wheat-soybean mealbased diet. The digestibility coefficients of starch and fat were enhanced with enzyme addition, from 93.1 to $97.3 \%$ and 89.3 to $92.5 \%$, respectively, and the retention of crude protein was also improved from 59.7 to $64.3 \%$. Woyengo et al. [185] fed pigs with a corn-soybean based diet, supplemented with a compound enzyme product (with 4000 $\mathrm{U}$ of xylanase, $150 \mathrm{U}$ of $\beta$-glucanase and $3000 \mathrm{U}$ of protease per kg of diet). The digestibility of "acid detergent fibre" and "neutral detergent fibre" (which are indicators of structural carbohydrate components such as the cell wall fraction of the feed) was improved by 21.1 and $42.0 \%$, respectively, compared to the control group without enzyme supplementation. The feed conversion ratio of the pigs (measured as gained body mass to feed mass ratio, G:F) also increased by $6.64 \%$ for the enzyme treated diet. Similar results were reported by Zhang et al. [186] using a commercial multi-enzyme product (containing amylase, protease and xylanase) as a dietary supplementation for a corn-soybean based feed supplied to 35-65 day old piglets. It was found that the nutrient digestibility was improved and the G:F ratio increased from 0.59 (in the control group) to 0.65 by the addition of the multi-enzyme product to the diet at a rate of $350 \mathrm{mg} / \mathrm{kg}$. Although the numerical increases in feed digestibility with enzyme addition reported in the literature appear relatively modest, they are considered to provide significant benefits in terms of the uptake and utilisation of dietary nutrients by animals [187].

The use of AS-recovered enzymes as animal feed additives has not yet been advocated, but is a technically feasible application for compound enzyme products derived from secondary resources. The potential adoption in feed manufacture would require the development of highly refined compound enzymes and would be subject to animal feed quality regulations to ensure livestock safety and to also protect the human food chain [188].

\section{Secondary Benefits of Enzyme Recovery from Activated Sludge}

Physical disruption of AS for enzyme recovery has several important secondary benefits for the subsequent treatment, management and utilisation of the residual sludge. The large amount of EPS in AS has a major influence on the sludge properties and LB-EPS, in particular, is responsible for the high content of bound water in sludge flocs, which reduces the compressibility and dewaterability of sludge [189]. Enzyme recovery is accompanied by sludge floc disruption, and EPS removal from microbial cells reduces the bound water content in the disrupted sludge, improving the overall settlement and dewaterability characteristics $[190$, 191]. Physical disruption of sludge flocs also increases organic matter solubilisation and anaerobic digestibility [192]. Martin et al. [193] showed that sonication treatment of mixed, and dehydrated, primary and secondary sludge prior to $\mathrm{AD}$ (carried out in an ultrasonic water bath with $150 \mathrm{~W}$ power input for $45 \mathrm{~min}$ at $25^{\circ} \mathrm{C}$ ) almost doubled the specific biogas yield from $88 \mathrm{~L} / \mathrm{kg}$ VS for the control (without pretreatment) to $172 \mathrm{~L} / \mathrm{kg}$ VS. Similarly, Chatterjee et al. [194] found the methane production of septic tank sludge increased from $299 \mathrm{~L} / \mathrm{kg}$ VS destroyed (specific methane yield: $224 \mathrm{~L} / \mathrm{kg} \mathrm{VS}$ ) in the control to $410 \mathrm{~L} /$ kg VS destroyed (specific methane yield: 337 L/kg VS) after sonication pretreatment (ultrasound frequency of $20 \mathrm{kHz}$ at a power of $100 \mathrm{~W}$ for $5 \mathrm{~min}$ ).

The disrupted sludge after enzyme extraction may also open other opportunities for resource recovery. For example, the AS residue contains a large fraction of cytoskeletal macromolecules and $\mathrm{Ni}$ et al. [56] proposed that this was suitable as a raw material for the production of superabsorbent polymers.

\section{Conclusions and Future Outlook}

Enzymes are bio-catalytic proteins that are used in a wide variety of industrial applications. An advantage of enzyme catalysed processes is that they demonstrate high reaction and substrate specificity, and, consequently, there are few if any side-reactions and little or no waste by-products. Furthermore, the reactions proceed within ambient range conditions and do not require high temperature or pressure environments. However, the extensive application of enzymes to major continuous industrial processes is limited due to their high cost, which is mainly associated with the microbial culture media. Biological AS produced by WWTP from the microbial hydrolysis and oxidation of organic substrates in municipal wastewater is a viable, 
potential alternative source of industrial enzymes and also offers both economic and operational advantages to the Water Industry.

The majority of hydrolytic enzymes with commercial value in AS are either embedded in the EPS fraction or adsorbed to the cell surface. Crude enzyme extraction following AS floc disruption has been demonstrated and is technically feasible in bench-scale experiments. Enzyme recovery can be achieved following different methods of extraction, by physical disruption of sludge and chemical extractant addition, alone or in combination, and successful laboratory procedures point to how this could be developed to full-scale. Sonication treatment was identified as the most favourable method for AS disruption and enzyme release, because it (1) is readily and simply adapted to continuous operation for industrial up-scaling, compared to bead milling, which requires additional processes to separate beads from the disrupted biomass, (2) can be readily optimised to maximise disruption efficiency and energy input by adjusting the duration, ultrasound frequency and solids content of the AS biomass material, and (3) can have a positive effect on the activity of extracted enzymes if operated under controlled conditions. Sonication is also a familiar technology to the Water Industry as a sludge disruption pretreatment for $\mathrm{AD}$. The optimum recovery method for a specific enzyme type can be designed depending on its location within the sludge floc and whether it is extracellular within the LB-EPS or TB-EPS, or attached to the cell surface, or intracellular, as this determines the ease of separation from microbial cells. However, in practice, at full-scale, it is likely that the objective will be to apply a relatively aggressive extraction method to AS incorporating sonication treatment in combination with surfactant addition. This procedure can extract the majority of enzymes in the EPS of AS flocs, to produce a compound hydrolytic enzyme formulation that is applicable for internal use on the WWTP or that can be marketed with further consolidation and purification for a wide range of industrial applications. For example, a direct internal market can be identified within WWTP to intensify the AD of sewage sludge by the addition of compound enzymes recovered from the waste AS sludge stream, to increase both the rate and total amount of biogas and renewable energy produced from sludge treated by the AD process. Enzyme pretreatment can also increase the extent of organic micropollutant destruction achieved during sewage sludge AD. Given the significant opportunities and advantages offered by enzyme extraction from AS, the next steps, therefore, should be to set up a pilot scale process as a precursor to industrial-scale implementation.

The balance of different extractable enzymes in AS is influenced by upstream wastewater management and is affected by the composition of the wastewater influent, the sludge age in the AS process, and the type of biological wastewater treatment reactor. Furthermore, other secondary waste materials, enriched with particular, target substrate types, can be incubated with AS biomass to induce and stimulate the expression of specific, specialised enzymes that are not typically present in the normal range of hydrolytic enzymes. This potentially offers major commercial opportunities to manipulate the enzyme yield from AS to produce specific high value enzymes that may be required for particular industrial applications. By exposing the AS biomass to anthropogenic organic chemicals, for example, this approach can also be applied to produce hydrolytic or oxidoreductase enzymes that can be engineered to increase micropollutant degradation in wastewater, sludge and other environmental media.

The crude enzyme extract from AS contains a mixture of enzymes (compound enzymes) and large amounts of microbial cellular substances and water. Consequently, the crude enzyme product is not biochemically stable and also has low economic value due to the relatively large volume. Therefore, consolidation and stabilisation are necessary to broaden the range of potential applications and the shelflife of the enzyme product. Carrier-free immobilisation (e.g. via cross-linking) combines purification and stabilisation of enzymes into a single step and is likely to be a promising approach to enhance the quality, utility and marketability of enzyme products extracted and recovered from wastewater AS. Further research is therefore necessary to optimise the purification and stabilisation of compound enzyme extracts from AS to produce industrially applicable formulations and also to determine their shelflife stability. The industrial uses of recovered and purified compound enzymes from AS are potentially extensive and can include, but are not limited to, biofuel production, animal feed supplementation, leather treatment, and detergent formulation.

Integrating enzyme recovery technology into current biological wastewater treatment systems is a technically feasible proposition to utilise waste AS for industrial enzyme production. Enzyme extraction from AS offers significant benefits to the Water Industry, including: (1) the recovery of valuable resources from wastewater, providing economic benefits to the operator, (2) facilitating enzyme addition as a practicable engineering option for sludge pretreatment to improve hydrolysis and digestibility and increase the biogas and renewable energy yield from $\mathrm{AD},(3)$ the destruction of organic micropollutants in wastewater and sludge to reduce chemical emissions from WWTP to the environment, (4) increasing the digestibility, settleability and dewaterability, of enzyme-extracted AS, thus improving the treatment and management of the residual solids from WWTP, (5) increasing the overall sustainability of WWTP, and (6) contributing to circular economy. 
Acknowledgements Ziyi Liu is supported by a $\mathrm{PhD}$ studentship from the China Scholarship Council and the financial contribution to the research by Yorkshire Water Services Limited is also gratefully acknowledged.

Open Access This article is licensed under a Creative Commons Attribution 4.0 International License, which permits use, sharing, adaptation, distribution and reproduction in any medium or format, as long as you give appropriate credit to the original author(s) and the source, provide a link to the Creative Commons licence, and indicate if changes were made. The images or other third party material in this article are included in the article's Creative Commons licence, unless indicated otherwise in a credit line to the material. If material is not included in the article's Creative Commons licence and your intended use is not permitted by statutory regulation or exceeds the permitted use, you will need to obtain permission directly from the copyright holder. To view a copy of this licence, visit http://creativecommons.org/licenses/by/4.0/.

\section{References}

1. Robinson, P.K.: Enzymes: principles and biotechnological applications. Essays Biochem. 59, 1-41 (2015)

2. Berg, J.M., Tymoczko, J.L., Stryer, L.: Biochemistry, 5th edn. W. H. Freeman, New York (2002)

3. Price, N., Stevens, L.: Fundamentals of Enzymology, 3rd edn. Oxford University Press, Oxford (1999)

4. Rupley, J.A., Gratton, E., Careri, G.: Water and globular proteins. Trends Biochem. Sci. 8(1), 18-22 (1983)

5. Bisswanger, H.: Introduction. In: Practical Enzymology, pp. 1-3. Wiley-VCH Verlag GmbH \& Co. KGaA, Weinheim (2011)

6. Hermes, J.D., Blacklow, S.C., Knowles, J.R.: The development of enzyme catalytic efficiency-an experimental approach. Cold Spring Harb. Symp. Quant. Biol. 52, 597-602 (1987)

7. Li, N., Zong, M.-H.: Lipases from the genus Penicillium: production, purification, characterization and applications. J. Mol. Catal. B 66(1), 43-54 (2010)

8. BCC Research: Global Markets for Enzymes in Industrial Applications. https://www.bccresearch.com/market-research/biote chnology/global-markets-for-enzymes-in-industrial-applicatio ns-bio030k.html (2018)

9. Haki, G.D., Rakshit, S.K.: Developments in industrially important thermostable enzymes: a review. Bioresour. Technol. 89(1), 17-34 (2003)

10. Zhou, C., Qin, H.L., Chen, X.J., Zhang, Y., Xue, Y.F., Ma, Y.H.: A novel alkaline protease from alkaliphilic Idiomarina sp C9-1 with potential application for eco-friendly enzymatic dehairing in the leather industry. Sci. Rep. 8, 16467 (2018)

11. Nadeem, F., Mehmood, T., Naveed, M., Shamas, S., Saman, T., Anwar, Z.: Protease production from Cheotomium globusum through central composite design using agricultural wastes and its immobilization for industrial exploitation. Waste Biomass Valoriz. (2019). https://doi.org/10.1007/s12649-019-00890-9

12. Khan, I., Ganesan, R., Dutta, J.R.: Probiotic lipase derived from Lactobacillus plantarum and Lactobacillus brevis for biodiesel production from waste cooking olive oil: an alternative feedstock. Int. J. Green Energy (2019). https://doi.org/10.1080/15435 075.2019.1688157

13. Wang, Y., Hu, H., Ma, J., Yan, Q., Liu, H., Jiang, Z.: A novel high maltose-forming $\alpha$-amylase from Rhizoтисо miehei and its application in the food industry. Food Chem. 305, 125447 (2020)

14. Gibson, W., Koch, C.: Biotechnology and Genetic Engineering, 1st edn. ED-Tech Press, Essex (2019)
15. Aberer, W., Hahn, M., Klade, M., Seebacher, U., Spok, A., Wallner, K., Witzani, H.: Collection of information on enzymes, vol. B4-3040/2000/278245/MAR/E2. European Communities, Luxembourg (2002)

16. Tyagi, V., Lo, S.L.: Sludge: a waste or renewable source for energy and resources recovery. Renew. Sustain. Energy Rev. 25, 708-728 (2013)

17. Wiltschi, B., Cernava, T., Dennig, A., Galindo Casas, M., Geier, M., Gruber, S., Haberbauer, M., Heidinger, P., Herrero Acero, E., Kratzer, R., Luley-Goedl, C., Müller, C.A., Pitzer, J., Ribitsch, D., Sauer, M., Schmölzer, K., Schnitzhofer, W., Sensen, C.W., Soh, J., Steiner, K., Winkler, C.K., Winkler, M., Wriessnegger, T.: Enzymes revolutionize the bioproduction of value-added compounds: from enzyme discovery to special applications. Biotechnol. Adv. 40, 107520 (2020)

18. Tchobanoglous, G., Burton, F.L., Stensel, H.D.: Metcalf, Eddy: Wastewater Engineering: Treatment and Resource Recovery, 5th edn. McGraw-Hill Higher Education, New York (2014)

19. Eurostat: Sewage sludge production and disposal from urban wastewater (in dry substance (d.s)). https://ec.europa.eu/euros tat/databrowser/view/ten00030/default/table?lang=en (2020). 2006

20. Gherghel, A., Teodosiu, C., De Gisi, S.: A review on wastewater sludge valorisation and its challenges in the context of circular economy. J. Clean. Prod. 228, 244-263 (2019)

21. Smith, S.R.: How activated sludge has been transformed from a waste to a resource, and the implications of this for the future of the activated sludge process. Paper presented at the Activated Sludge: Past, Present and Future, Manchester, UK, 2-3 April, 2014

22. Shaddel, S., Bakhtiary-Davijany, H., Kabbe, C., Dadgar, F., Osterhus, S.W.: Sustainable sewage sludge management: from current practices to emerging nutrient recovery technologies. Sustainability 11(12), 3435 (2019)

23. Liu, Z., Smith, S.R.: Enzyme activity of waste activated sludge extracts. Water Sci. Technol. (2020). https://doi.org/10.2166/ wst.2020.002

24. Boczar, B.A., Begley, W.M., Larson, R.J.: Characterization of enzyme activity in activated sludge using rapid analyses for specific hydrolases. Water Environ. Res. 64(6), 792-797 (1992)

25. Szilveszter, S., Raduly, B., Miklóssy, I., Ábrahám, B., Szabolcs, L., Nicolae, D.: Enzymatic activity studies of biological wastewater treatment. Studia Universitatis Babeș-Bolyai. Chemia (2009)

26. Wingender, J., Neu, T.R., Flemming, H.-C.: What are bacterial extracellular polymeric substances? In: Microbial Extracellular Polymeric Substances, pp. 1-19. Springer, Berlin (1999)

27. Jung, J., Xing, X.H., Matsumoto, K.: Kinetic analysis of disruption of excess activated sludge by Dyno Mill and characteristics of protein release for recovery of useful materials. Biochem. Eng. J. 8(1), 1-7 (2001)

28. Gessesse, A., Dueholm, T., Petersen, S.B., Nielsen, P.H.: Lipase and protease extraction from activated sludge. Water Res. 37(15), 3652-3657 (2003)

29. Nabarlatz, D., Vondrysova, J., Jenicek, P., Stuber, F., Font, J., Fortuny, A., Fabregat, A., Bengoa, C.: Hydrolytic enzymes in activated sludge: extraction of protease and lipase by stirring and ultrasonication. Ultrason. Sonochem. 17(5), 923-931 (2010)

30. Liu, Y., Fang, H.H.P.: Influences of extracellular polymeric substances (EPS) on flocculation, settling, and dewatering of activated sludge. Crit. Rev. Environ. Sci. Technol. 33(3), 237-273 (2003)

31. Wang, B.B., Chang, Q., Peng, D.C., Hou, Y.P., Li, H.J., Pei, L.Y.: A new classification paradigm of extracellular polymeric 
substances (EPS) in activated sludge: separation and characterization of exopolymers between floc level and microcolony level. Water Res. 64, 53-60 (2014)

32. Zou, J.T., Tao, Y.Q., Li, J., Wu, S.Y., Ni, Y.J.: Cultivating aerobic granular sludge in a developed continuous-flow reactor with twozone sedimentation tank treating real and low-strength wastewater. Bioresour. Technol. 247, 776-783 (2018)

33. He, Q.L., Zhang, J., Gao, S.X., Chen, L., Lyu, W.L., Zhang, W., Song, J.Y., Hu, X.L., Chen, R.F., Wang, H.Y., Yu, J.: A comprehensive comparison between non-bulking and bulking aerobic granular sludge in microbial communities. Bioresour. Technol. 294, 122151 (2019)

34. Teuber, M., Brodisch, K.E.U.: Enzymatic activities of activated sludge. Eur. J. Appl. Microbiol. Biotechnol. 4(3), 185-194 (1977)

35. Dold, P.L., Fleit, E., Han, J., Copp, J.B.: Assay for determination of $\alpha$-amylase activity in activated sludge mixed bacterial communities. Environ. Technol. 16(2), 181-188 (1995)

36. Goel, R., Mino, T., Satoh, H., Matsuo, T.: Comparison of hydrolytic enzyme systems in pure culture and activated sludge under different electron acceptor conditions. Water Sci. Technol. 37(45), 335-343 (1998)

37. Confer, D.R., Logan, B.E.: Location of protein and polysaccharide hydrolytic activity in suspended and biofilm wastewater cultures. Water Res. 32(1), 31-38 (1998)

38. Kloeke, F.V., Geesey, G.G.: Localization and identification of populations of phosphatase-active bacterial cells associated with activated sludge flocs. Microb. Ecol. 38(3), 201-214 (1999)

39. Li, Y., Chrost, R.J.: Enzymatic activities in petroleum wastewater purification system by an activated sludge process. J. Microbiol. Biotechnol. 16(2), 200-204 (2006)

40. Yu, G.H., He, P.J., Shao, L.M., Lee, D.J.: Enzyme activities in activated sludge flocs. Appl. Microbiol. Biotechnol. 77(3), 605-612 (2007)

41. Lin, H., Zhang, M., Wang, F., Meng, F., Liao, B.-Q., Hong, H., Chen, J., Gao, W.: A critical review of extracellular polymeric substances (EPSs) in membrane bioreactors: characteristics, roles in membrane fouling and control strategies. J. Membr. Sci. 460(Supplement C), 110-125 (2014)

42. Cadoret, A., Conrad, A., Block, J.C.: Availability of low and high molecular weight substrates to extracellular enzymes in whole and dispersed activated sludges. Enzym. Microb. Technol. 31(1-2), 179-186 (2002)

43. Karn, S.K., Kumar, P., Pan, X.L.: Extraction of lipase and protease and characterization of activated sludge from pulp and paper industry. Prep. Biochem. Biotechnol. 43(2), 152-162 (2013)

44. Trzcinski, A.P.: Advanced Biological, Physical, and Chemical Treatment of Waste Activated Sludge, 1st edn. CRC Press, Boca Raton (2018)

45. Frolund, B., Griebe, T., Nielsen, P.H.: Enzymatic-activity in the activated-sludge floc matrix. Appl. Microbiol. Biotechnol. 43(4), 755-761 (1995)

46. Guellil, A., Boualam, M., Quiquampoix, H., Ginestet, P., Audic, J.M., Block, J.C.: Hydrolysis of wastewater colloidal organic matter by extracellular enzymes extracted from activated sludge flocs. Water Sci. Technol. 43(6), 33-40 (2001)

47. Levine, A.D., Tchobanoglous, G., Asano, T.: Size distributions of particulate contaminants in wastewater and their impact on treatability. Water Res. 25(8), 911-922 (1991)

48. Levine, A.D., Tchobanoglous, G., Asano, T.: Characterization of the size distribution of contaminants in wastewater: treatment and reuse implications. Journal (Water Pollution Control Federation) 57(7), 805-816 (1985)

49. Chrost, R.J.: Environmental-control of the synthesis and activity of aquatic microbial ectoenzymes. In: Chrost, R.J. (ed.) Microbial
Enzymes in Aquatic Environments, pp. 29-59. Springer-Verlag, New York (1991)

50. Hou, X., Liu, S., Zhang, Z.: Role of extracellular polymeric substance in determining the high aggregation ability of anammox sludge. Water Res. 75, 51-62 (2015)

51. Hoppe, H.-G., Kim, S.-J., Gocke, K.: Microbial decomposition in aquatic environments: combined process of extracellular enzyme activity and substrate uptake. Appl. Environ. Microbiol. 54(3), 784-790 (1988)

52. Nybroe, O., Jorgensen, P.E., Henze, M.: Enzyme activities in waste water and activated sludge. Water Res. 26(5), 579-584 (1992)

53. Yu, G.H., He, P.J., Shao, L.M., Zhu, Y.S.: Enzyme extraction by ultrasound from sludge flocs. J. Environ. Sci. 21(2), 204-210 (2009)

54. Nabarlatz, D., Stuber, F., Font, J., Fortuny, A., Fabregat, A., Bengoa, C.: Extraction and purification of hydrolytic enzymes from activated sludge. Resour. Conserv. Recycl. 59, 9-13 (2012)

55. Krah, D., Ghattas, A.K., Wick, A., Bröder, K., Ternes, T.A.: Micropollutant degradation via extracted native enzymes from activated sludge. Water Res. 95, 348-360 (2016)

56. Ni, H., Fan, X.M., Guo, H.N., Liang, J.H., Li, Q.R., Yang, L., Li, H., Li, H.H.: Comprehensive utilization of activated sludge for the preparation of hydrolytic enzymes, polyhydroxyalkanoates, and water-retaining organic fertilizer. Prep. Biochem. Biotechnol. 47(6), 611-618 (2017)

57. Rubin, D.M., Anderton, N., Smalberger, C., Polliack, J., Nathan, M., Postema, M.: On the behaviour of living cells under the influence of ultrasound. Fluids 3(4), 82 (2018)

58. Zielinski, M., Debowski, M., Kisielewska, M., Nowicka, A., Rokicka, M., Szwarc, K.: Comparison of ultrasonic and hydrothermal cavitation pretreatments of cattle manure mixed with straw wheat on fermentative biogas production. Waste Biomass Valoriz. 10(4), 747-754 (2019)

59. Balasundaram, B., Harrison, S.T.L.: Study of physical and biological factors involved in the disruption of $E$. coli by hydrodynamic cavitation. Biotechnol. Prog. 22(3), 907-913 (2006)

60. Zielewicz, E.: Effects of ultrasonic disintegration of excess sewage sludge. Appl. Acoust. 103, 182-189 (2016)

61. Onyeche, T.I., Schläfer, O., Bormann, H., Schröder, C., Sievers, M.: Ultrasonic cell disruption of stabilised sludge with subsequent anaerobic digestion. Ultrasonics 40(1), 31-35 (2002)

62. Vardanega, R., Santos, D.T., Meireles, M.A.A.: Intensification of bioactive compounds extraction from medicinal plants using ultrasonic irradiation. Pharmacogn. Rev. 8(16), 88-95 (2014)

63. Coussios, C.C., Farny, C.H., Ter Haar, G., Roy, R.A.: Role of acoustic cavitation in the delivery and monitoring of cancer treatment by high-intensity focused ultrasound (HIFU). Int. J. Hyperth. 23(2), 105-120 (2007)

64. Lee, J.: Importance of sonication and solution conditions on the acoustic cavitation activity. In: Handbook of Ultrasonics and Sonochemistry, pp. 137-175. Springer, Singapore (2016)

65. Neppiras, E.A.: Acoustic cavitation series: part one: acoustic cavitation: an introduction. Ultrasonics 22(1), 25-28 (1984)

66. Avvaru, B., Pandit, A.B.: Oscillating bubble concentration and its size distribution using acoustic emission spectra. Ultrason. Sonochem. 16(1), 105-115 (2009)

67. Tiehm, A., Nickel, K., Zellhorn, M., Neis, U.: Ultrasonic waste activated sludge disintegration for improving anaerobic stabilization. Water Res. 35(8), 2003-2009 (2001)

68. Yasuda, K., Kato, D., Xu, Z., Sakka, M., Sakka, K.: Effect of ultrasonic frequency on enzymatic hydrolysis of cellulose. Jpn. J. Appl. Phys. 49(7), 07HE08 (2010) 
69. Nadar, S.S., Rathod, V.K.: Ultrasound assisted intensification of enzyme activity and its properties: a mini-review. World J. Microbiol. Biotechnol. 33(9), 170 (2017)

70. Subhedar, P.B., Gogate, P.R.: Intensification of enzymatic hydrolysis of lignocellulose using ultrasound for efficient bioethanol production: a review. Ind. Eng. Chem. Res. 52(34), 11816-11828 (2013)

71. Sponer, J.: Dependence of the cavitation threshold on the ultrasonic frequency. Czech J. Phys. 40(10), 1123-1132 (1990)

72. Nguyen, T.T., Asakura, Y., Koda, S., Yasuda, K.: Dependence of cavitation, chemical effect, and mechanical effect thresholds on ultrasonic frequency. Ultrason. Sonochem. 39, 301-306 (2017)

73. Zhang, P., Zhang, G., Wang, W.: Ultrasonic treatment of biological sludge: floc disintegration, cell lysis and inactivation. Bioresour. Technol. 98(1), 207-210 (2007)

74. Monique, R., Elisabeth, G.N., Etienne, P., Dominique, L.: A high yield multi-method extraction protocol for protein quantification in activated sludge. Bioresour. Technol. 99(16), 7464-7471 (2008)

75. Hong, P.N., Honda, R., Noguchi, M., Ito, T.: Optimum selection of extraction methods of extracellular polymeric substances in activated sludge for effective extraction of the target components. Biochem. Eng. J. 127, 136-146 (2017)

76. Arun, C., Sivashanmugam, P.: Study on optimization of process parameters for enhancing the multi-hydrolytic enzyme activity in garbage enzyme produced from preconsumer organic waste. Bioresour. Technol. 226, 200-210 (2017)

77. Tyagi, V.K., Lo, S.L., Appels, L., Dewil, R.: Ultrasonic treatment of waste sludge: a review on mechanisms and applications. Crit. Rev. Environ. Sci. Technol. 44(11), 1220-1288 (2014)

78. Show, K.Y., Mao, T., Lee, D.J.: Optimisation of sludge disruption by sonication. Water Res. 41(20), 4741-4747 (2007)

79. Huang, G., Chen, S., Dai, C., Sun, L., Sun, W., Tang, Y., Xiong, F., He, R., Ma, H.: Effects of ultrasound on microbial growth and enzyme activity. Ultrason. Sonochem. 37, 144-149 (2017)

80. Zielewicz, E.: Effects of ultrasonic disintegration of excess sewage sludge. Top. Curr. Chem. (2016). https://doi.org/10.1007/ s41061-016-0068-5

81. Abramov, O.V.: Low-amplitude vibrations and waves. In: HighIntensity Ultrasonics: Theory and Industrial Applications, pp. 8-95. CRC Press, London (1999)

82. Tytla, M., Zielewicz, E.: The effect of ultrasonic disintegration process conditions on the physicochemical characteristics of excess sludge. Arch. Environ. Prot. 42(1), 19-26 (2016)

83. Zhang, G.M., Zhang, P.Y., Yang, J., Liu, H.Z.: Energy-efficient sludge sonication: power and sludge characteristics. Bioresour. Technol. 99(18), 9029-9031 (2008)

84. Abbasi, M., Dehghani, M., Moussavi, G., Azhdarpoor, A.: Degradation of organic matter of municipal sewage sludge using ultrasound treatment in Shiraz wastewater treatment plant. Health Scope 4(1), e23507 (2015)

85. Pilli, S., Bhunia, P., Yan, S., LeBlanc, R.J., Tyagi, R.D., Surampalli, R.Y.: Ultrasonic pretreatment of sludge: a review. Ultrason. Sonochem. 18(1), 1-18 (2011)

86. Richard, M.T.: Activated sludge microbiology problems and their control. Paper presented at the 20th Annual USEPA National Operator Trainers Conference, Buffalo, New York, June 8, 2003

87. Li, A-j, Li, X-y, Yu, H-q: Effect of the food-to-microorganism (F/M) ratio on the formation and size of aerobic sludge granules. Process Biochem. 46(12), 2269-2276 (2011)

88. Li, Z., Stenstrom, M.K.: Impacts of SRT on particle size distribution and reactor performance in activated sludge processes. Water Environ. Res. 90(1), 48-56 (2018)

89. Eriksson, L., Steen, I., Tendaj, M.: Evaluation of sludge properties at an activated-sludge plant. Water Sci. Technol. 25(6), 251-265 (1992)
90. Liu, Y., Yang, H., Takatsuki, H., Sakanishi, A.: Effect of ultrasonic exposure on $\mathrm{Ca} 2+-\mathrm{ATPase}$ activity in plasma membrane from Aloe arborescens callus cells. Ultrason. Sonochem. 13(3), 232-236 (2006)

91. Ladole, M.R., Mevada, J.S., Pandit, A.B.: Ultrasonic hyperactivation of cellulase immobilized on magnetic nanoparticles. Bioresour. Technol. 239, 117-126 (2017)

92. Capelo, J.L., Ximenez-Embun, P., Madrid-Albarran, Y., Camara, C.: Enzymatic probe sonication: enhancement of protease-catalyzed hydrolysis of selenium bound to proteins in yeast. Anal. Chem. 76(1), 233-237 (2004)

93. Wett, B., Phothilangka, P., Eladawy, A.: Systematic comparison of mechanical and thermal sludge disintegration technologies. Waste Manag. 30(6), 1057-1062 (2010)

94. Baier, U., Schmidheiny, P.: Enhanced anaerobic degradation of mechanically disintegrated sludge. Water Sci. Technol. 36(11), 137-143 (1997)

95. Postma, P.R., Miron, T.L., Olivieri, G., Barbosa, M.J., Wijffels, R.H., Eppink, M.H.M.: Mild disintegration of the green microalgae Chlorella vulgaris using bead milling. Bioresour. Technol. 184, 297-304 (2015)

96. Clavijo Rivera, E., Montalescot, V., Viau, M., Drouin, D., Bourseau, P., Frappart, M., Monteux, C., Couallier, E.: Mechanical cell disruption of Parachlorella kessleri microalgae: impact on lipid fraction composition. Bioresour. Technol. 256, 77-85 (2018)

97. Safi, C., Cabas Rodriguez, L., Mulder, W.J., Engelen-Smit, N., Spekking, W., van den Broek, L.A.M., Olivieri, G., Sijtsma, L.: Energy consumption and water-soluble protein release by cell wall disruption of Nannochloropsis gaditana. Bioresour. Technol. 239, 204-210 (2017)

98. Geciova, J., Bury, D., Jelen, P.: Methods for disruption of microbial cells for potential use in the dairy industry-a review. Int. Dairy J. 12(6), 541-553 (2002)

99. Suarez Garcia, E., Lo, C., Eppink, M.H.M., Wijffels, R.H., van den Berg, C.: Understanding mild cell disintegration of microalgae in bead mills for the release of biomolecules. Chem. Eng. Sci. 203, 380-390 (2019)

100. Koubaa, M., Imatoukene, N., Drévillon, L., Vorobiev, E.: Current insights in yeast cell disruption technologies for oil recovery: a review. Chem. Eng. Process. 150, 107868 (2020)

101. Currie, J.A., Dunnill, P., Lilly, M.D.: Release of protein from bakers-yeast (Saccharomyces cerevisiae) by disruption in an industrial agitator mill. Biotechnol. Bioeng. 14(5), 725 (1972)

102. Montalescot, V., Rinaldi, T., Touchard, R., Jubeau, S., Frappart, M., Jaouen, P., Bourseau, P., Marchal, L.: Optimization of bead milling parameters for the cell disruption of microalgae: process modeling and application to Porphyridium cruentum and Nannochloropsis oculata. Bioresour. Technol. 196, 339-346 (2015)

103. Lehne, G., Muller, A., Schwedes, J.: Mechanical disintegration of sewage sludge. Water Sci. Technol. 43(1), 19-26 (2001)

104. Rai, C.L., Mueller, J., Struenkmann, G., Rao, P.G.: Microbial growth reduction in sewage sludge by stirred ball mill disintegration and estimation by respirometry. J. Chem. Technol. Biotechnol. 83(3), 269-278 (2008)

105. Melendres, A.V., Honda, H., Shiragami, N., Unno, H.: A kinetic analysis of cell disruption by bead mill. The influence of bead loading, bead size and agitator speed. Bioseparation 2(4), 231$236(1991)$

106. Middelberg, A.P.: Process-scale disruption of microorganisms. Biotechnol. Adv. 13(3), 491-551 (1995)

107. Günerken, E., D’Hondt, E., Eppink, M.H.M., Garcia-Gonzalez, L., Elst, K., Wijffels, R.H.: Cell disruption for microalgae biorefineries. Biotechnol. Adv. 33(2), 243-260 (2015)

108. Lv, J.P., Zhao, F., Feng, J., Liu, Q., Nan, F.R., Xie, S.L.: Extraction of extracellular polymeric substances (EPS) from a newly 
isolated self-flocculating microalga Neocystis mucosa SX with different methods. Algal Res. (2019). https://doi.org/10.1016/j. algal.2019.101479

109. Li, D.X., Xi, H.L.: Layered extraction and adsorption performance of extracellular polymeric substances from activated sludge in the enhanced biological phosphorus removal process. Molecules 24(18), 3358 (2019)

110. Felz, S., Al-Zuhairy, S., Aarstad, O.A., van Loosdrecht, M.C.M., Lin, Y.M.: Extraction of structural extracellular polymeric substances from aerobic granular sludge. J. Vis. Exp. (2016). https ://doi.org/10.3791/54534

111. Lu, Q., Chang, M., Yu, Z., Zhou, S.G.: The effects of three commonly used extraction methods on the redox properties of extracellular polymeric substances from activated sludge. Environ. Technol. 36(22), 2884-2891 (2015)

112. Wawrzynczyk, J., Szewczyk, E., Norrlow, O., Dey, E.S.: Application of enzymes, sodium tripolyphosphate and cation exchange resin for the release of extracellular polymeric substances from sewage sludge - characterization of the extracted polysaccharides/glycoconjugates by a panel of lectins. J. Biotechnol. 130(3), 274-281 (2007)

113. Merrylin, J., Kaliappan, S., Kumar, S.A., Yeom, I.T., Rajesh, B.J.: Effect of extracellular polymeric substances on sludge reduction potential of Bacillus licheniformis. Int. J. Environ. Sci. Technol. 10(1), 85-92 (2013)

114. Park, C., Novak, J.T., Helm, R.F., Ahn, Y.O., Esen, A.: Evaluation of the extracellular proteins in full-scale activated sludges. Water Res. 42(14), 3879-3889 (2008)

115. Sheng, G.-P., Yu, H.-Q., Yu, Z.: Extraction of extracellular polymeric substances from the photosynthetic bacterium Rhodopseudomonas acidophila. Appl. Microbiol. Biotechnol. 67(1), 125-130 (2005)

116. Franz, A.W., Kronemayer, H., Pfeiffer, D., Pilz, R.D., Reuss, G., Disteldorf, W., Gamer, A.O., Hilt, A.: Formaldehyde. In: Ullmann's Encyclopedia of Industrial Chemistry, pp. 1-34. WileyVCH Verlag GmbH \& Co. KGaA, Berlin (2016)

117. Khoirunnisa, W., Puspitarini, S., Rohmawati, S.A., Eltavia, F., Rahayu, R.P., Utomo, D.H., Permatasari, G.W.: Molecular mechanism of formaldehyde and protein interaction in human cancer cell. Trends Bioinform. 9(1), 30-34 (2016)

118. Comte, S., Guibaud, G., Baudu, M.: Relations between extraction protocols for activated sludge extracellular polymeric substances (EPS) and EPS complexation properties: part I. Comparison of the efficiency of eight EPS extraction methods. Enzym. Microb. Technol. 38(1), 237-245 (2006)

119. Alasonat, E., Slaveykova, V.L.: Effects of extraction methods on the composition and molar mass distributions of exopolymeric substances of the bacterium Sinorhizobium meliloti. Bioresour. Technol. 114, 603-609 (2012)

120. Anbazhagan, S., Palani, S.: Extraction of consortium of hydrolytic enzymes from waste activated sludge using ultrasonication and stirring with surfactants. Ultrason. Sonochem. 40, 874-880 (2018)

121. Koley, D., Bard, A.J.: Triton X-100 concentration effects on membrane permeability of a single HeLa cell by scanning electrochemical microscopy (SECM). Proc. Natl. Acad. Sci. USA 107(39), 16783-16787 (2010)

122. Karn, S.K., Kumar, A.: Protease, lipase, and amylase extraction and optimization from activated sludge of pulp and paper industry. Indian J. Exp. Biol. 57(3), 201-205 (2019)

123. Sethupathy, A., Sivashanmugam, P.: Investigation on ultrasonication mediated biosurfactant disintegration method in sludge flocs for enhancing hydrolytic enzymes activity and polyhydroxyalkanoates. Environ. Technol. 40(27), 3547-3560 (2019)

124. Feng, Q., Tai, X.R., Sun, Y.Q., Li, M.: Influence of turbulent mixing on the composition of extracellular polymeric substances
(EPS) and aggregate size of aerated activated sludge. Chem. Eng. J. (2019). https://doi.org/10.1016/j.cej.2019.122123

125. Ye, F.X., Peng, G., Li, Y.: Influences of influent carbon source on extracellular polymeric substances (EPS) and physicochemical properties of activated sludge. Chemosphere 84(9), 1250-1255 (2011)

126. Li, Y., Chrost, R.J.: Microbial enzymatic activities in aerobic activated sludge model reactors. Enzym. Microb. Technol. 39(4), 568-572 (2006)

127. Yu, G.H., He, P.J., Shao, L.M., Lee, D.: Extracellular enzymes in sludge flocs collected at 14 full-scale wastewater treatment plants. J. Chem. Technol. Biotechnol. 83(12), 1717-1725 (2008)

128. Liu, Z., Yang, H., Huang, Z., Zhou, P., Liu, S.J.: Degradation of aniline by newly isolated, extremely aniline-tolerant Delftia sp AN3. Appl. Microbiol. Biotechnol. 58(5), 679-682 (2002)

129. Bai, N.L., Wang, S., Abuduaini, R., Zhu, X.F., Zhao, Y.H.: Isolation and characterization of Sphingomonas sp Y2 capable of high-efficiency degradation of nonylphenol polyethoxylates in wastewater. Environ. Sci. Pollut. Res. 23(12), 12019-12029 (2016)

130. Hao, Z., Jahng, D.: Variations of organic matters and extracellular enzyme activities during biodrying of dewatered sludge with different bulking agents. Biochem. Eng. J. 147, 126-135 (2019)

131. Clara, M., Kreuzinger, N., Strenn, B., Gans, O., Kroiss, H.: The solids retention time- a suitable design parameter to evaluate the capacity of wastewater treatment plants to remove micropollutants. Water Res. 39(1), 97-106 (2005)

132. Garcia, J., Fernandez, S., Mirada, F.J., Lopez, F.: Determination of the protease activity in activated sludges by gelatin hydrolysis. J. Environ. Sci. Health A 32(9-10), 2537-2551 (1997)

133. Loupasaki, E., Diamadopoulos, E.: Attached growth systems for wastewater treatment in small and rural communities: a review. J. Chem. Technol. Biotechnol. 88(2), 190-204 (2013)

134. Hassard, F., Biddle, J., Harnett, R., Stephenson, T.: Microbial extracellular enzyme activity affects performance in a full-scale modified activated sludge process. Sci. Total Environ. 625, 1527-1534 (2018)

135. Kovárová-Kovar, K., Egli, T.: Growth kinetics of suspended microbial cells: from single-substrate-controlled growth to mixed-substrate kinetics. Microbiol. Mol. Biol. Rev. 62(3), 646-666 (1998)

136. Ramos, O.S., Malcata, F.X.: Food-grade enzymes. In: MooYoung, M. (ed.) Comprehensive Biotechnology, vol. 3, pp. 555-569. Academic Press, Burlington (2011)

137. Atha, D.H., Ingham, K.C.: Mechanism of precipitation of proteins by polyethylene glycols-analysis in terms of excluded volume. J. Biol. Chem. 256(23), 2108-2117 (1981)

138. Qin, Y., Fu, Y., Li, Q., Luo, F., He, H.: Purification and enzymatic properties of a difunctional glycoside hydrolase from Aspergillus oryzae HML366. Indian J. Microbiol. 60, 475-484 (2020). https://doi.org/10.1007/s12088-020-00892-5

139. Hmidet, N., Bayoudh, A., Berrin, J.G., Kanoun, S., Juge, N., Nasri, M.: Purification and biochemical characterization of a novel alpha-amylase from Bacillus licheniformis $\mathrm{NH1}$ - cloning, nucleotide sequence and expression of amyN gene in Escherichia coli. Process Biochem. 43(5), 499-510 (2008)

140. Jung, J., Xing, X.H., Matsumoto, K.: Recoverability of protease released from disrupted excess sludge and its potential application to enhanced hydrolysis of proteins in wastewater. Biochem. Eng. J. 10(1), 67-72 (2002)

141. Sharma, R., Chisti, Y., Banerjee, U.C.: Production, purification, characterization, and applications of lipases. Biotechnol. Adv. 19(8), 627-662 (2001)

142. Coskun, O.: Separation techniques: chromatography. North Clin. Istanb. 3(2), 156-160 (2016) 
143. Erat, M., Demir, H., Šakiroglu, H.: Purification of glutathione reductase from chicken liver and investigation of kinetic properties. Appl. Biochem. Biotechnol. 125(2), 127-138 (2005)

144. D'Souza, D.H., Bhattacharya, S., Das, A.: Fibrinolytic protease from Bacillus cereus S46: purification, characterization, and evaluation of its in vitro thrombolytic potential. J. Basic Microbiol. 60(8), 661-668 (2020)

145. Vidya, C.H., Kumar, B.S.G., Chinmayee, C.V., Singh, S.A.: Purification, characterization and specificity of a new GH family 35 galactosidase from Aspergillus awamori. Int. J. Biol. Macromol. 156, 885-895 (2020)

146. Batista, J.M.S., Brandao-Costa, R.M.P., da Cunha, M.N.C., Rodrigues, H.O.S., Porto, A.L.F.: Purification and biochemical characterization of an extracellular fructosyltransferase-rich extract produced by Aspergillus tamarii Kita UCP1279. Biocatal. Agric. Biotechnol. 26, 101647 (2020)

147. Sahutoglu, A.S., Akgul, C.: Immobilisation of Aspergillus oryzae alpha-amylase and Aspergillus niger glucoamylase enzymes as cross-linked enzyme aggregates. Chem. Pap. 69(3), 433-439 (2015)

148. Sheldon, R.A., van Pelt, S.: Enzyme immobilisation in biocatalysis: why, what and how. Chem. Soc. Rev. 42(15), 62236235 (2013)

149. Katchalskikatzir, E.: Immobilized enzymes-learning from past successes and failures. Trends Biotechnol. 11(11), 471478 (1993)

150. Bisswanger, H.: Enzymes in technical applications. In: Practical Enzymology, pp. 297-336. Wiley-VCH Verlag GmbH \& Co. KGaA, Weinheim (2011)

151. Schoevaart, R., Wolbers, M.W., Golubovic, M., Ottens, M., Kieboom, A.P.G., van Rantwijk, F., van der Wielen, L.A.M., Sheldon, R.A.: Preparation, optimization, and structures of cross-linked enzyme aggregates (CLEAs). Biotechnol. Bioeng. 87(6), 754-762 (2004)

152. Cao, L.Q., van Rantwijk, F., Sheldon, R.A.: Cross-linked enzyme aggregates: a simple and effective method for the immobilization of penicillin acylase. Org. Lett. 2(10), 13611364 (2000)

153. Asgher, M., Bashir, F., Iqbal, H.M.N.: Protease-based crosslinked enzyme aggregates with improved catalytic stability, silver removal, and dehairing potentials. Int. J. Biol. Macromol. 118, $1247-1256$ (2018)

154. Cui, J., Lin, T., Feng, Y., Tan, Z., Jia, S.: Preparation of spherical cross-linked lipase aggregates with improved activity, stability and reusability characteristic in water-in-ionic liquid microemulsion. J. Chem. Technol. Biotechnol. 92(7), 1785-1793 (2017)

155. Yamaguchi, H., Kiyota, Y., Miyazaki, M.: Techniques for preparation of cross-linked enzyme aggregates and their applications in bioconversions. Catalysts 8(5), 174 (2018)

156. Jannat, M., Yang, K.L.: Immobilization of enzymes on flexible tubing surfaces for continuous bioassays. Langmuir 34(47), 14226-14233 (2018)

157. Barber, E.A., Liu, Z., Smith, S.R.: Organic contaminant biodegradation by oxidoreductase enzymes in wastewater treatment. Microorganisms 8(1), 122 (2020)

158. Damasceno, F.R.C., Freire, D.M.G., Cammarota, M.C.: Impact of the addition of an enzyme pool on an activated sludge system treating dairy wastewater under fat shock loads. J. Chem. Technol. Biotechnol. 83(5), 730-738 (2008)

159. Mackul'ak, T., Bodik, I., Smolinska, M., Takacova, A., Drtil, M., Gal, M., Faberova, M.: Automotive industry wastewater treatment by mixture of enzymes. Monatsh. Chem. 147(1), 159-164 (2016)

160. Mobarak-Qamsari, E., Kasra-Kermanshahi, R., Nosrati, M., Amani, T.: Enzymatic pre-hydrolysis of high fat content dairy wastewater as a pretreatment for anaerobic digestion. Int. J. Environ. Res. 6(2), 475-480 (2012)

161. Lohri, C.R., Diener, S., Zabaleta, I., Mertenat, A., Zurbrügg, C.: Treatment technologies for urban solid biowaste to create value products: a review with focus on low- and middle-income settings. Rev. Environ. Sci. Bio/Technol. 16(1), 81-130 (2017)

162. Donoso-Bravo, A., Retamal, C., Carballa, M., Ruiz-Filippi, G., Chamy, R.: Influence of temperature on the hydrolysis, acidogenesis and methanogenesis in mesophilic anaerobic digestion: parameter identification and modeling application. Water Sci. Technol. 60(1), 9-17 (2009)

163. Lindeboom, R.E.F., Ding, L., Weijma, J., Plugge, C.M., van Lier, J.B.: Starch hydrolysis in autogenerative high pressure digestion: gelatinisation and saccharification as rate limiting steps. Biomass Bioenerg. 71, 256-265 (2014)

164. Chen, J.H., Liu, S.H., Wang, Y.M., Huang, W., Zhou, J.: Effect of different hydrolytic enzymes pretreatment for improving the hydrolysis and biodegradability of waste activated sludge. Water Sci. Technol. 2017, 592-602 (2018)

165. Arun, C., Sivashanmugam, P.: Solubilization of waste activated sludge using a garbage enzyme produced from different preconsumer organic waste. RSC Adv. 5(63), 51421-51427 (2015)

166. Yin, Y., Liu, Y.J., Meng, S.J., Kiran, E.U., Liu, Y.: Enzymatic pretreatment of activated sludge, food waste and their mixture for enhanced bioenergy recovery and waste volume reduction via anaerobic digestion. Appl. Energy 179, 1131-1137 (2016)

167. Bonilla, S., Choolaei, Z., Meyer, T., Edwards, E.A., Yakunin, A.F., Allen, D.G.: Evaluating the effect of enzymatic pretreatment on the anaerobic digestibility of pulp and paper biosludge. Biotechnol. Rep. 17, 77-85 (2018)

168. Bahreini, G., Nazari, L., Ho, D., Flannery, C.C., Elbeshbishy, E., Santoro, D., Nakhla, G.: Enzymatic pre-treatment for enhancement of primary sludge fermentation. Bioresour. Technol. 305, 123071 (2020)

169. Zhou, H., Zhang, Z., Wang, M., Hu, T., Wang, Z.: Enhancement with physicochemical and biological treatments in the removal of pharmaceutically active compounds during sewage sludge anaerobic digestion processes. Chem. Eng. J. 316, 361-369 (2017)

170. Zhou, H.D., Liu, J.C., Chen, X.M., Ying, Z.X., Zhang, Z., Wang, M.: Fate of pharmaceutically active compounds in sewage sludge during anaerobic digestions integrated with enzymes and physicochemical treatments. Waste Manag. 78, 911-916 (2018)

171. Hoppe, W., Lohmann, W., Markl, H., Ziegler, H.: Biophysics. Springer Verlag, Berlin (1983)

172. Mañas, P., Muñoz, B., Sanz, D., Condón, S.: Inactivation of lysozyme by ultrasonic waves under pressure at different temperatures. Enzym. Microb. Technol. 39(6), 1177-1182 (2006)

173. Selvakumar, P., Sivashanmugam, P.: Ultrasound assisted oleaginous yeast lipid extraction and garbage lipase catalyzed transesterification for enhanced biodiesel production. Energy Convers. Manag. 179, 141-151 (2019)

174. Abu Yazid, N., Barrena, R., Sanchez, A.: Assessment of protease activity in hydrolysed extracts from SSF of hair waste by and indigenous consortium of microorganisms. Waste Manag. 49, 420-426 (2016)

175. Niyonzima, F.N.: Detergent-compatible bacterial cellulases. J. Basic Microbiol. 59(2), 134-147 (2019)

176. Hasan, F., Shah, A.A., Javed, S., Hameed, A.: Enzymes used in detergents: lipases. Afr. J. Biotechnol. 9(31), 4836-4844 (2010)

177. Zhang, J., Zhang, Y., Li, W., Li, X.L., Lian, X.: Optimizing detergent formulation with enzymes. J. Surfactants Deterg. 17(6), 1059-1067 (2014)

178. Thebti, W., Riahi, Y., Belhadj, O.: Purification and characterization of a new thermostable, haloalkaline, solvent stable, 
and detergent compatible serine protease from Geobacillus toebii strain LBT 77. Biomed. Res. Int. (2016). https://doi. org/10.1155/2016/9178962

179. El Hadj-Ali, N., Agrebi, R., Ghorbel-Frikha, B., SellamiKamoun, A., Kanoun, S., Nasri, M.: Biochemical and molecular characterization of a detergent stable alkaline serine-protease from a newly isolated Bacillus licheniformis NH1. Enzym. Microb. Technol. 40(4), 515-523 (2007)

180. Soleimani, M., Khani, A., Najafzadeh, K.: alpha-Amylase immobilization on the silica nanoparticles for cleaning performance towards starch soils in laundry detergents. J. Mol. Catal. B 74(12), 1-5 (2012)

181. Ojha, B.K., Singh, P.K., Shrivastava, N.: Enzymes in the animal feed industry. In: Kuddus, M. (ed.) Enzymes in Food Biotechnology: Production, Applications, and Future Prospects, pp. 93-109. Academic Press, Cambridge (2019)

182. Campbell, G.L., Bedford, M.R.: Enzyme applications for monogastric feeds-a review. Can. J. Anim. Sci. 72(3), 449-466 (1992)

183. Brufau, J., Francesch, M., Perez-Vendrell, A.M.: The use of enzymes to improve cereal diets for animal feeding. J. Sci. Food Agric. 86(11), 1705-1713 (2006)

184. Kalmendal, R., Tauson, R.: Effects of a xylanase and protease, individually or in combination, and an ionophore coccidiostat on performance, nutrient utilization, and intestinal morphology in broiler chickens fed a wheat-soybean meal-based diet. Poult. Sci. 91(6), 1387-1393 (2012)

185. Woyengo, T., Ampaire, A., Li, W.: Growth performance and nutrient digestibility of weaned pigs fed multi-enzyme supplemented corn-soybean meal-based diets. J. Anim. Sci. 96, 329329 (2018)

186. Zhang, G.G., Yang, Z.B., Wang, Y., Yang, W.R., Zhou, H.J.: Effects of dietary supplementation of multi-enzyme on growth performance, nutrient digestibility, small intestinal digestive enzyme activities, and large intestinal selected microbiota in weanling pigs1. J. Anim. Sci. 92(5), 2063-2069 (2014)

187. Montoya-Mejía, M., Hernández-Llamas, A., García-Ulloa, M., Nolasco-Soria, H., Gutierrez-Dorado, R., Rodríguez-González,
H.: Apparent digestibility coefficient of chickpea, maize, highquality protein maize, and beans diets in juvenile and adult Nile tilapia (Oreochromis niloticus). Revista Brasileira de Zootecnia 45, 427-432 (2016)

188. European Parliament and Council of the European Union: Regulation (EC) No 1831/2003 of the European Parliament and of the Council of 22 September 2003 on additives for use in animal nutrition. Official Journal of the European Union L 268, 29-43 (2003)

189. Li, X.Y., Yang, S.F.: Influence of loosely bound extracellular polymeric substances (EPS) on the flocculation, sedimentation and dewaterability of activated sludge. Water Res. 41(5), 1022-1030 (2007)

190. Atay, S., Akbal, F.: Classification and effects of sludge disintegration technologies integrated into sludge handling units: an overview. Clean-Soil Air Water 44(9), 1198-1213 (2016)

191. Iritani, E., Katagiri, N., Yamada, M., Hwang, K.J., Cheng, T.W.: Ultrahigh-pressure expression of activated sludge assisted with self-flocculation caused by ultrasonication. Chem. Eng. Res. Des. 112, 16-23 (2016)

192. Salsabil, M.R., Prorot, A., Casellas, M., Dagot, C.: Pre-treatment of activated sludge: effect of sonication on aerobic and anaerobic digestibility. Chem. Eng. J. 148(2-3), 327-335 (2009)

193. Martin, M.A., Gonzalez, I., Serrano, A., Siles, J.A.: Evaluation of the improvement of sonication pre-treatment in the anaerobic digestion of sewage sludge. J. Environ. Manag. 147, 330-337 (2015)

194. Chatterjee, P., Ghangrekar, M.M., Rao, S.: Biogas production from partially digested septic tank sludge and its kinetics. Waste Biomass Valoriz. 10(2), 387-398 (2019)

Publisher's Note Springer Nature remains neutral with regard to jurisdictional claims in published maps and institutional affiliations. 